\title{
Temporal variations in microbenthic metabolism and inorganic nitrogen fluxes in sandy and muddy sediments of a tidally dominated bay in the northern Wadden Sea
}

\author{
E. Kristensen, M. H. Jensen \& K. M. Jensen \\ Institute of Biology, Odense University; DK-5230 Odense M, Denmark
}

\begin{abstract}
Factors controlling seasonal variations in benthic metabolism $\left(\mathrm{O}_{2}\right.$ flux $)$ and dissolved inorganic nitrogen (DIN) fluxes were examined during a 12-14 month period at three intertidal Wadden Sea stations. Since the flux measurements were made as small-scale laboratory core incubations, the results are primarily related to the microbenthic community (microalgae, bacteria, micro-, meio- and small macrofauna) and cannot be considered representative of the total benthic community in the Wadden Sea. Furthermore, it has to be emphasized that light intensity during daytime simulations were constant and saturating at all times. Benthic primary production and oxygen uptake appeared to be temperature dependent with a 'seasonal $\mathrm{Q}_{10}$ ' of 1.7-1.8 and 2.7-4.3, respectively. Inundation had no effect on oxygen fluxes as evidenced by similar sediment respiration with and without water cover. A stronger temperature dependence of primary production in muddy than in sandy sediment indicated that the overall control in the latter may be complex due to factors like macrofaunal grazing and nutrient availability. Benthic respiration may not be controlled by temperature alone, as sedimentary organic matter content correlated significantly with both temperature and benthic respiration. Annual gross primary production in high intertidal sandy sediment was 10 and $50 \%$ higher than in low intertidal sandy and muddy sediments, respectively. Since annual benthic community respiration was 2 times higher in muddy than sandy sediments, the annual net primary production was about 0 in the former and $17-19 \mathrm{~mol} \mathrm{C} \mathrm{m}^{-2} \mathrm{yr}^{-1}$ in the latter. However, heterotrophic contribution by larger faunal components as well as removal of organic carbon by waves and tidal currents, which are not included here, may balance the budget at the sandy stations. There was no or only weak relationships between (light and dark) DIN exchange and factors like temperature, sedimentary organic content, and oxygen fluxes. Factors related to nutrient fluxes, such as denitrification and nutrient concentration in the overlying water, may have hampered any such relationships. In fact, DIN fluxes at all three stations appeared to be strongly controlled by DIN concentrations in the overlying water. On an annual basis, the sediment appeared to be a net sink for DIN.
\end{abstract}

\section{INTRODUCTION}

Intertidal areas, like the Wadden Sea, are characterized by a highly fluctuating physical and chemical environment. Benthic communities (microalgae, bacteria and animals) in such areas must endure large variations in factors like temperature, salinity, waves and currents on time scales of hours (e.g. diurnal and tidal cycles) to months (e.g. seasons). In addition, the activity of benthic primary producers and decomposers are highly dependent upon the light, nutrients and organic matter regime (van Es, 1982; Davis \& McIntire, 1983; Kristensen, 1993). Our understanding of these important controlling factors for 
benthic metabolism is further complicated by the fact that their relative role may vary substantially within and between intertidal habitats (Cadée \& Hegeman, 1977; Hargrave et al., 1983; Grant, 1986; Sampou \& Oviatt, 1991).

Many studies have adressed the response of individual components of the benthic community toward variations in one or few environmental parameters (e.g. Admiraal \& Peletier, 1980; Rasmussen et al., 1983; van Duyl \& Kop, 1990), while relatively few have examined the simultaneous community response towards a number of dominating parameters (e.g. Hargrave et al., 1983; Grant, 1986; Kristensen, 1993). Community level processes, such as $\mathrm{O}_{2}$ demand and dissolved inorganic nitrogen (DIN) exchange, have been widely used to determine the metabolic activity of the benthos in a variety of environments (e.g. Jørgensen \& Sørensen, 1985; Nowicki \& Nixon, 1985a; Rizzo, 1990; Kristensen, 1993). By studying the combined action of a multitude of parameters on these processes we will improve our understanding of system behaviour to naturally occurring events, although specific details of response patterns for each individual parameter may be obscured.

The present study was conducted to examine the temporal behaviour of microbenthic primary producers (i.e. diatoms and cyanobacteria) and heterotrophs (i.e. bacteria, micro-, meio- and small macrofauna) in three different sediment environments of a small Wadden Sea area. The exchange of $\mathrm{O}_{2}, \mathrm{CO}_{2}$, and DIN were measured in the laboratory at bimonthly intervals over a period of 1.5 years. The laboratory incubations were carried out under the prevailing temperature and DIN concentrations, whereas light intensity was constant and saturating during daylight simulations. In addition to possible correlations with various environmental parameters, the results were examined for any inter-relationship between gas exchange and nutrient exchange in the light and the dark.

\section{MATERIALS AND METHODS}

\section{Study site}

Königshafen is a tidally dominated bay at the northern tip of the island of Sylt (northern part of the German Wadden Sea, southwest North Sea) covering $5.5 \mathrm{~km}^{2}$ (Fig. 1). The bay is protected from the prevailing winds and wave action from west by sand dunes and is open to the Wadden Sea on the east coast of the island of Sylt. About $75 \%$ of the bay is intertidal and tidal waters enter the bay through one tidal gully (Asmus \& Asmus, 1996; Backhaus et al., 1996). Tidal range is $1.8 \mathrm{~m}$ and salinity ranges from $23 \%$ in winter to $33 \%$ in summer.

The sediments of the bay vary in grain-size spectrum from mud to cobbles (Austen, 1994). At the head of the bay, where protection from prevailing winds and waves creates a deposition area, the sediment is fine grained with a modal particle size of $<0.1$ (Fig. 1). The central, low intertidal part of the bay is dominated by fine sand with a modal particle size of 0.1 to $0.2 \mathrm{~mm}$, whereas medium sand with a modal particle size of 0.2 to $0.35 \mathrm{~mm}$ is characteristic of the high intertidal areas. Large parts of the south and north shores are dominated by coarse sand with a modal particle size $>0.35 \mathrm{~mm}$. It has been suggested that the presence of coarse and medium sand in high intertidal Königshafen sediments is due to aeolian input from adjacent dunes (Austen, 1994).

The benthic fauna consists of relatively few species with a specific dominant compo- 


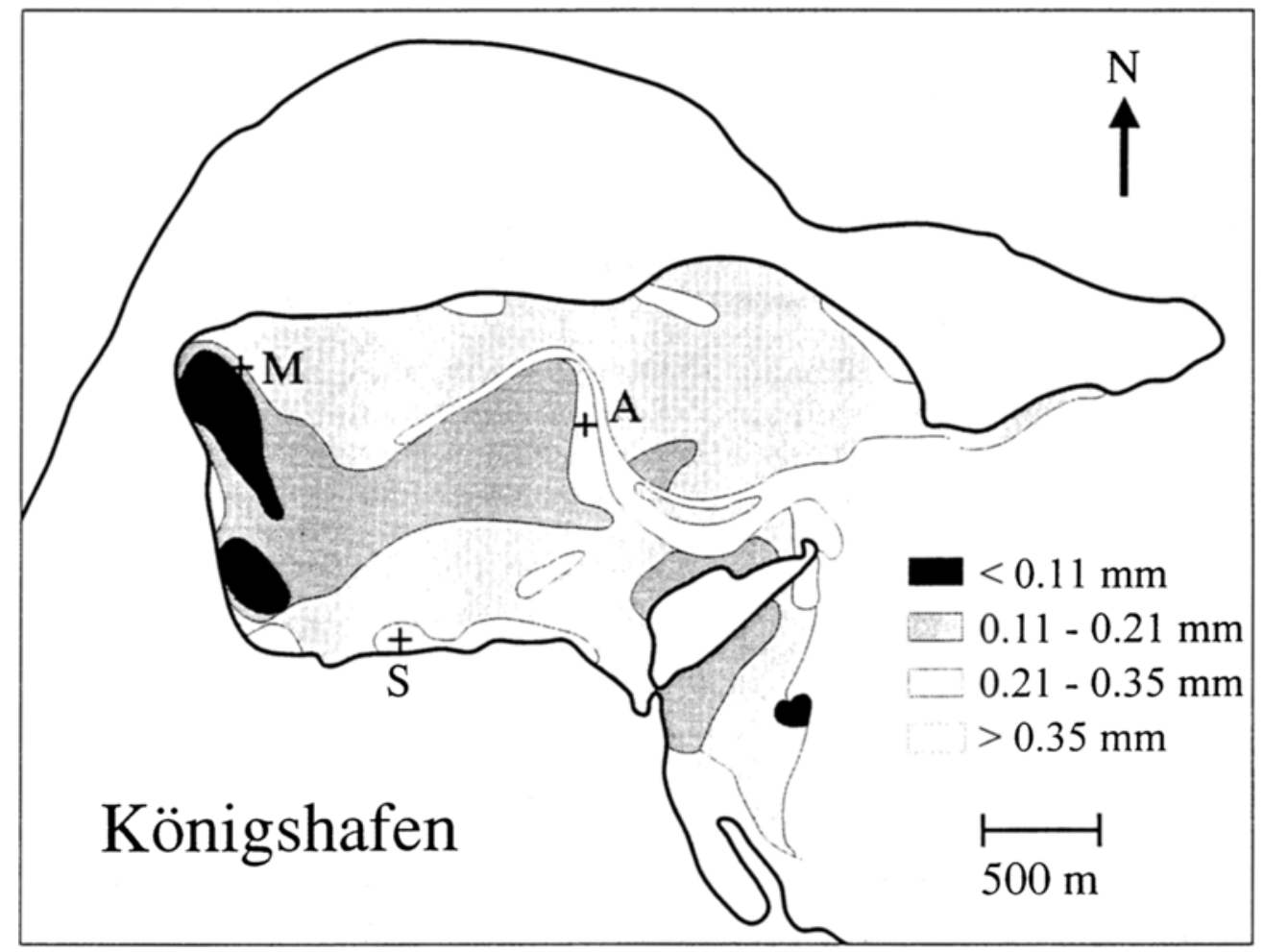

Fig. 1. Map of the study area, Königshafen, on the Island of Sylt, German Wadden Sea. The 3 investigated stations are shown with indications of the modal grain size of the major sediment types (redrawn after Austen, 1994)

nent in each of the dominant sediment types (Jensen et al., 1996). The epifaunal mudsnail, Hydrobia ulvae, dominates in the high intertidal coarse sands with densities ranging from $5000 \mathrm{~m}^{-2}$ in winter to $10000-25000 \mathrm{~m}^{-2}$ in summer. Arenicola marina dominates in the fine and medium sands of the central part of Königshafen with densities higher than $50 \mathrm{~m}^{-2}$ all year round (Reise et al., 1994). The dominant benthic faunal species in the muddy area at the head of the bay is the cockle, Cerastoderma edule, with densities ranging from 150 to $300 \mathrm{~m}^{-2}$.

The macro-vegetation is dominated by seagrasses of the genus Zostera. The sandy areas have a scattered coverage of Zostera marina and $Z$. noltii, whereas only the former is present in the muddy sand area.

\section{Sampling}

Cores were sampled in bimonthly intervals (each sampling period lasting 1-2 weeks) from April 1993 to July 1994 at the 3 stations: S, A, and M (Fig. 1). Station S is a coarse sand site close to the south shore; station $\mathrm{A}$ is a low-intertidal medium sand site; and station $M$ is located at the transition between mud and fine sand at the head of the bay. Or- 
ganic content at the two former stations varies between 0.5 and $1.0 \% \mathrm{dw}$ (LOI), whereas the latter station exhibits values of 2-6\%. Although the inundation time within the entire bay varies between 0 and $12 \mathrm{~h}$ per tidal cycle, a range of $4-6 \mathrm{~h}$ is typical at the study sites (Jensen et al., 1996).

Sediment cores for determination of fluxes and sediment parameters were sampled by hand in daylight during water cover, using 25 (and occasionally 15)-cm long, 8-cm $\varnothing$ core tubes (fluxes) and $30-\mathrm{cm}$ long, $5-\mathrm{cm} \varnothing$ core tubes (sediment parameters). At each sampling date and station, 4-9 (usually 6 ) parallel cores $(\approx 10 \mathrm{~cm}$ sediment depth and $\approx 10 \mathrm{~cm}$ water column) were taken for light and dark flux incubations, and 3 parallel cores were taken for determination of sediment parameters. As cores were sampled from areas with no trace of Zostera spp., the results obtained here should be considered representative only of non-vegetated areas in Königshafen. Furthermore, the size of core tubes used for flux incubations prevented a representative inclusion of the dominant faunal feature, Arenicola marina, at station A. Adult individuals of this polychaete are usually buried below the core sampling depth and are as such not accounted for here.

\section{Flux measurements}

Sediment-water fluxes of gases and nutrients. After transfer to the laboratory at the "Wattenmeerstation Sylt", all flux cores were pre-incubated with stirring under light by submersing them uncapped into an aerated tank containing circulating, unfiltered seawater from the area for a few hours prior to the light/dark incubations. Stirring of the water column in cores was provided by spinning magnets (60-70 rpm) receiving momentum from an external magnet. We deliberately used unfiltered water to mimic ambient conditions. Tests showed that errors introduced in the benthic flux measurements due to processes occurring in the water column were negligible.

At each sampling period one specific temperature was used for dark incubations at all stations. The chosen temperature was the average value of flood water at the start of the sampling period. During light incubations, the temperature was slightly higher $\left(1-2^{\circ} \mathrm{C}\right)$ due to heating from the light source used. Irrespective of season and station, all cores received the same light intensity at the sediment-water interface (about $200 \mu \mathrm{E} \mathrm{m}^{-2} \mathrm{~s}^{-1}$ ) supplied by a 400 watt Mercury-halogen lamp placed $60 \mathrm{~cm}$ above the sediment. This light intensity is close to the saturation level for benthic diatoms (Rasmussen et al., 1983).

After the pre-incubation period, cores were first incubated for flux measurements in light and subsequently in darkness. The incubations were initiated by taking water samples for $\mathrm{O}_{2}, \mathrm{CO}_{2}$ (occasionally), and DIN $\left(\mathrm{NH}_{4}{ }^{+}, \mathrm{NO}_{2}{ }^{-}, \mathrm{NO}_{3}{ }^{-}\right.$) from each core before they were capped and incubated with stirred water phases. The light incubations were terminated by the final samplings after 0.15 to $2.50 \mathrm{~h}$ (depending on season). Incubation time for light fluxes was kept short in order to minimize any underestimation of gas fluxes due to bubble formation. Fluxes in darkness were measured following a $4-5 \mathrm{~h}$ pre-incubation of the same cores in the dark. During the first 3-4 $h$, the overlying water was removed and the cores were kept with the sediment exposed to air in order to simulate a low tide situation. After the cores were flooded again and kept open (and stirred) for a few hours, the dark incubation was performed similar to the light incubation, except that cores were incubated for periods of 0.2 to $17.0 \mathrm{~h}$. Fluxes were determined from the concentration dif- 
ference between initial and final samples by assuming a linear change in concentration over time. Occasionally this assumption was investigated and verified.

Water samples for $\mathrm{O}_{2}$ measurements were transferred to gas tight 25 -ml glass bottles and analysed within 1-2 h using the standard Winkler technique. Samples for $\mathrm{CO}_{2}$ were transferred to 10-ml gas-tight Exetainers with screw caps (excluding any headspace) and preserved with $10 \mu \mathrm{l}$ of $50 \% \mathrm{HgCl}_{2}$. These samples were later analysed by the flow injection/diffusion cell technique of Hall \& Aller (1992) using a Kontron Ion Chromatograph. Samples for $\mathrm{NH}_{4}{ }^{+}$and $\mathrm{NO}_{3}{ }^{-}$(since $\mathrm{NO}_{2}{ }^{-}$was low in concentration, it is included in the $\mathrm{NO}_{3}{ }^{-}$data) were stored frozen and later analysed using the standard autoanalyzer methods of Solorzano (1969) for $\mathrm{NH}_{4}{ }^{+}$and Armstrong et al. (1967) for $\mathrm{NO}_{3}^{-}$. The 1994 samples of $\mathrm{NH}_{4}{ }^{+}$were analysed by the manual salicylate hypochlorite method of Bower \& Holm-Hansen (1980).

Sediment-air flux of oxygen. Dark $\mathrm{O}_{2}$ uptake by the sediment at low tide was determined from the $\mathrm{O}_{2}$ change in the headspace of sealed, air-exposed cores (Kristensen et al., 1992). A number of $2-3$ cores $(\approx 11 \mathrm{~cm}$ sediment depth and $\approx 3 \mathrm{~cm}$ headspace) were acclimated to the chosen temperature for 1-2 $\mathrm{h}$ in the laboratory. After the acclimation period, a rubber stopper, with a Clark-type $\mathrm{O}_{2}$ electrode (Radiometer, Denmark) inserted through a hole in the center, was fitted to the core liner allowing only $1-2 \mathrm{~cm}$ headspace (corresponding to a volume of $50-100 \mathrm{ml}$ air) above the sediment. The final electrode reading was noted after $8-16 \mathrm{~h}$. Subsequently, the stopper and $\mathrm{O}_{2}$ electrode was transferred to a core liner half-filled with distilled water at the same temperature and the $\mathrm{O}_{2}$ reading in water-saturated atmosphere (equivalent to the start concentration) was noted after about 15 min equilibration. Oxygen uptake was calculated on the basis of the concentration change and air volume trapped below the rubber stopper.

\section{Sediment parameters}

Sediment cores for the determination of sediment parameters were cut into $0.3-\mathrm{cm}$ (upper section) to $2.0-\mathrm{cm}$ slices. Subsamples of each slice were analysed for porosity by determination of wet density (weight of known volume) and water content (drying at $105^{\circ} \mathrm{C}$ for $24 \mathrm{~h}$ ). Organic content was determined on the dried sediment as loss-on-ignition (LOI) at $520^{\circ} \mathrm{C}$ for $6 \mathrm{~h}$.

Chlorophyll a was measured on 0.5 to $1.0-\mathrm{cm}$ slices in the upper $5 \mathrm{~cm}$ of the sediment according to the method of Parsons et al. (1984). Samples of about $0.5 \mathrm{~g}$ wet sediment from each slice were immediately stored frozen $\left(-18^{\circ} \mathrm{C}\right)$. Subsequently, all samples were tranferred to glass centrifuge tubes and extracted with $5 \mathrm{ml}$ of $90 \%$ acetone for $24 \mathrm{~h}$ at $5{ }^{\circ} \mathrm{C}$. After centrifugation at $3000 \mathrm{rpm}$, the supernatant was analysed spectrophotometrically at 665 and $750 \mathrm{~nm}$ before and after acidification with 2 drops of $1 \mathrm{M} \mathrm{HCl}$.

\section{RESULTS}

\section{Sediment characteristics}

The presence of microphytobenthos and freshly deposited allochthonous organic matter at the two sandy stations, $\mathrm{S}$ and $\mathrm{A}$, was evident as an enrichment from a background organic content of $0.2-0.4 \%$ LOI to about $0.8 \%$ in the upper $0-3 \mathrm{~mm}$ of the sedi- 
ment (Fig. 2). The difference in texture between these two sediments was thus not reflected in the organic content. At the muddy station, $M$, the depth pattern of LOI was very heterogenous with an enrichment at the sediment-water interface (annual average $3 \%$ LOI) and a subsurface peak around $4-6 \mathrm{~cm}$ depth (about $4 \%$ LOI) followed by a second subsurface peak below $15 \mathrm{~cm}$ depth (Fig. 2). These zones corresponded to the transitions of sediment texture between "loose" muddy sand, "compact" mud/silt, sand and clayish mud. Beside the presence of benthic diatoms at the surface, the primary source of organic matter at the muddy station was (decaying) seagrasses and macroalgae. Water content, which was highly correlated with LOI, ranged between 15 and $30 \%$ at S and $\mathrm{A}$, and between 16 and $51 \%$ at $M$.

The organic content in the upper $3 \mathrm{~mm}$ of the sediment showed a distinct seasonal variation. At the two sandy stations ( $\mathrm{S}$ and A), LOI varied from about $0.5 \%$ in winter to $1 \%$ in summer (Fig. 3), whereas the muddy sediment (M) covered a range of 1 to $6 \%$ LOI over the same two seasons.

Chlorophyll a concentrations in the sediment, which can be used as an indicator of fresh and labile organic matter, generally decreased with depth in the sediment at all three stations. The concentration of $\mathrm{Chl}$. $a$ at the sediment surface (annual averages at

\section{Loss on Ignition (\% d.w.)}

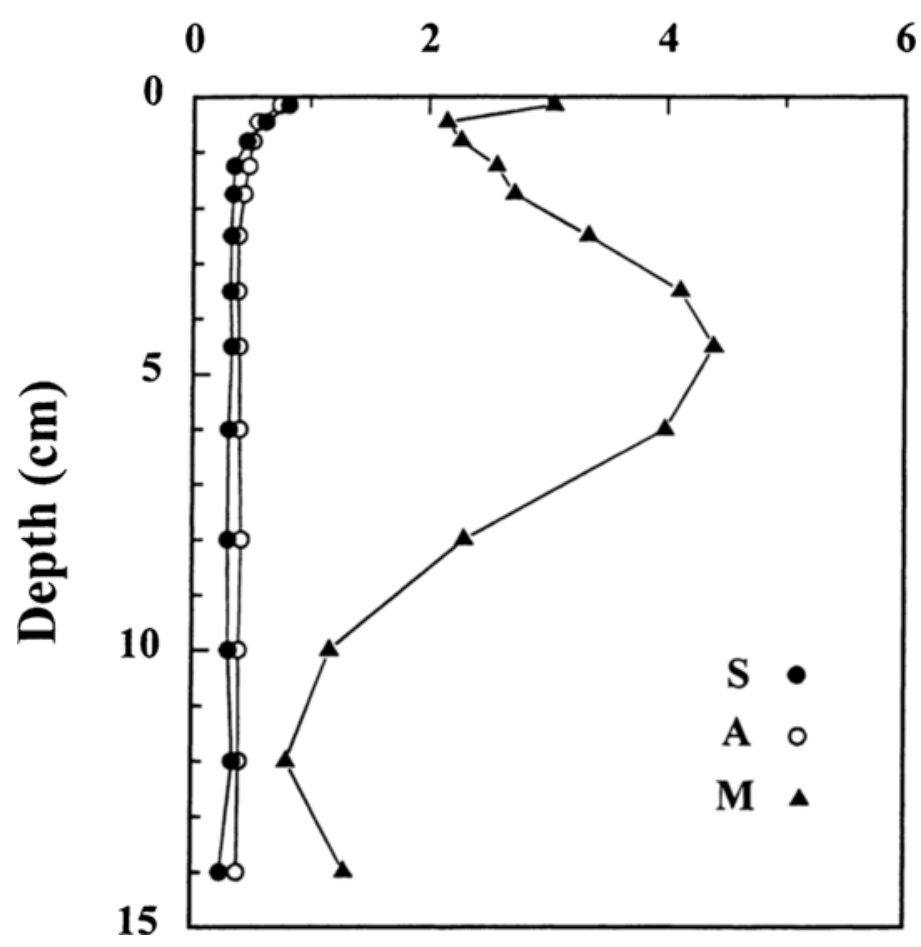

Fig. 2. Vertical profiles of organic content (measured as loss on ignition) in the upper $15 \mathrm{~cm}$ of the sediment at the 3 Königshafen stations. The data are seasonal averages 


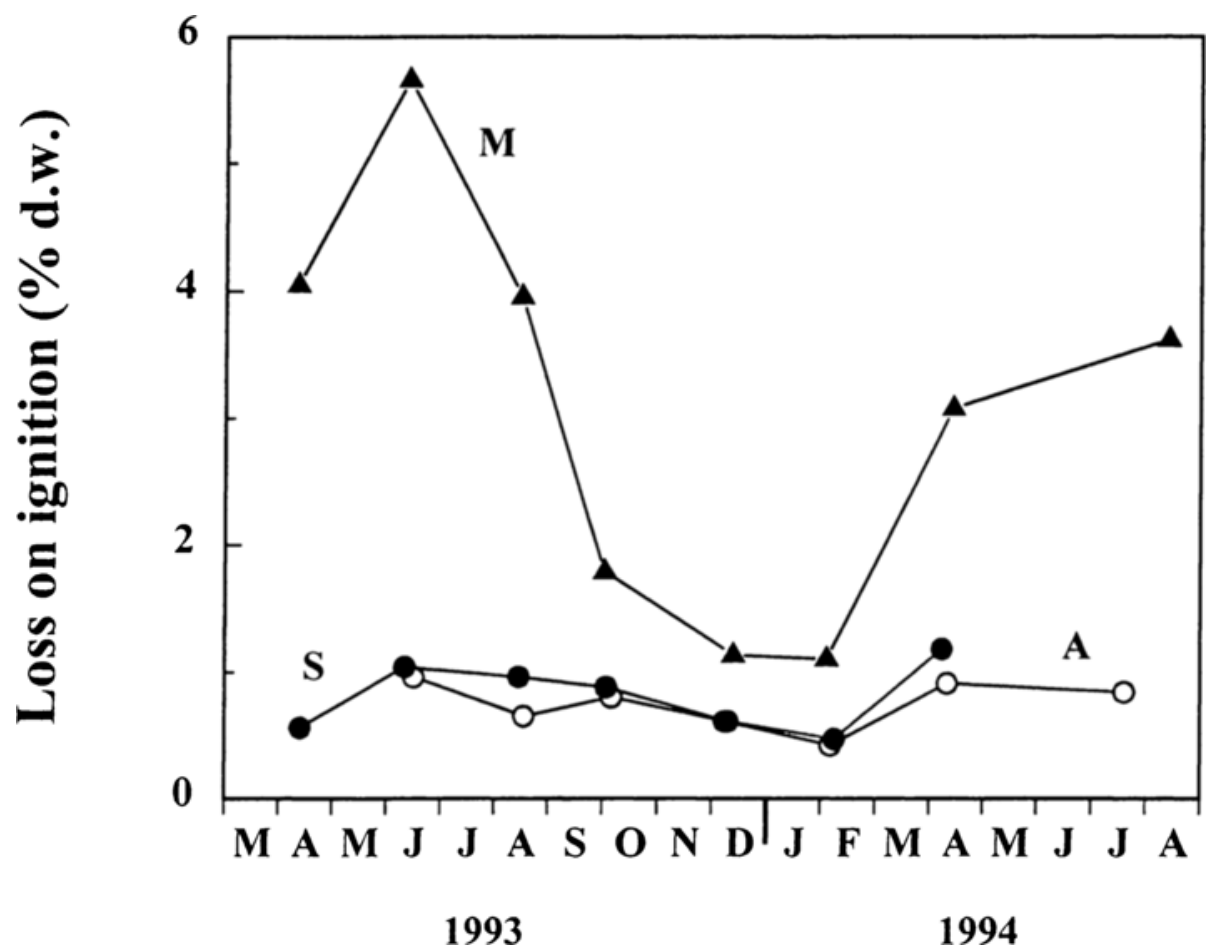

Fig. 3. Seasonal variation in the organic content (LOI) of the upper $3 \mathrm{~mm}$ of the sediment at the 3 Königshafen stations

$0-0.5 \mathrm{~cm})$ was highest at station $\mathrm{M}\left(13.3 \pm 1.8 \mu \mathrm{g}[\mathrm{g} \mathrm{ww}]^{-1}\right)$, intermediate at station A $\left(10.7 \pm 1.7 \mu \mathrm{g}[\mathrm{g} \mathrm{ww}]^{-1}\right)$, and lowest at station $\mathrm{S}\left(9.1 \pm 1.3 \mu \mathrm{g}[\mathrm{g} \mathrm{ww}]^{-1}\right)$. The attenuation with depth followed the same sequence between stations, as the annual average Chl. a concentration at $4-5 \mathrm{~cm}$ depth was $46 \%$ of the surface level at M, 39\% at A and $27 \%$ at $\mathrm{S}$.

The seasonal variation in Chl. a was most pronounced in the surface sediment and quite different among the stations (Fig. 4). There was a distinct surface Chl. a peak in winter (December) at $\mathrm{S}$, in autumn (October) at $\mathrm{A}$, and in summer (July-August) at M. However, due to an unfortunate loss of samples from spring 1994, any changes during this period remain undetected. Temporal changes in Chl. a decreased with depth in the sediment, and at 4-5 cm depth there were virtually no changes detected (except for an unexplained peak at station $M$ in July 1994). When present (at station $S$ and $A$ ), the lower seasonal changes at intermediate depths $(1.5-2 \mathrm{~cm})$ occurred with several months delay compared to those in the surface layer. 

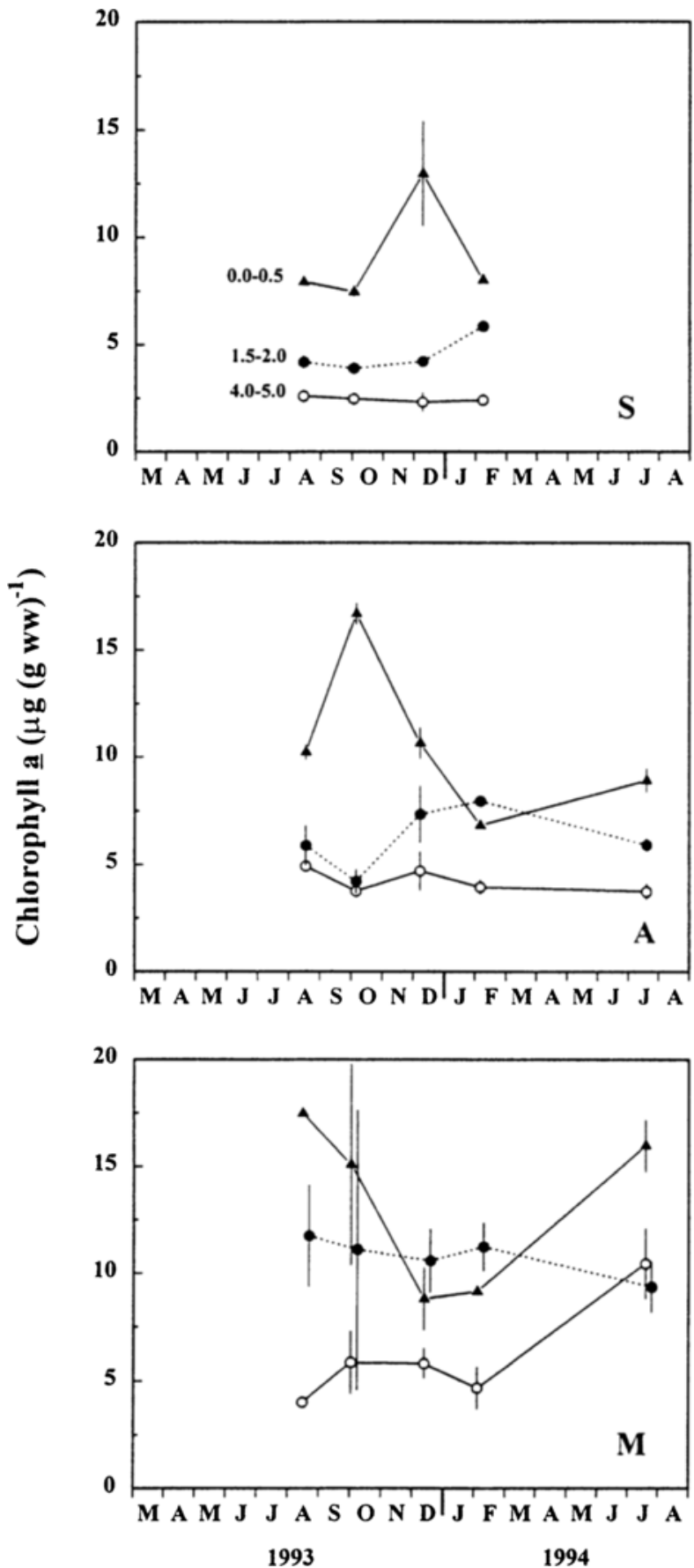

Fig. 4. Seasonal variation of chlorophyll $a$ in three depth intervals $(0-0.5,1.5-2$ and $4-5 \mathrm{~cm})$ of the sediment at the 3 Königshafen stations. Results are given as averages \pm S.E. $(n=3)$ 


\section{Microbenthic primary production and respiration}

Benthic $\mathrm{O}_{2}$ fluxes obtained in light represent net microbenthic primary production (NPP) by diatoms and cyanobacteria (excluding macroflora). Negative NPP (i.e. net uptake by the sediment) were never observed at any of the three stations during the study period (Fig. 5). NPP maxima were temporally displaced at the stations and a year-to-year variation was also evident. At the coarse sand station, S, NPP was relatively low and constant throughout $1993\left(2-3 \mathrm{mmol} \mathrm{m}^{-2} \mathrm{~h}^{-1}\right)$, whereas in 1994 a pronounced spring maximum developed with a peak in April $\left(10 \mathrm{mmol} \mathrm{m}^{-2} \mathrm{~h}^{-1}\right)$. A different pattern was found at the fine sand station, A, where a seasonal pattern was observed in both 1993 and 1994 with a maximum in early autumn (September-October) of $9-10 \mathrm{mmol} \mathrm{m}^{-2} \mathrm{~h}^{-1}$ and a minimum in winter (December-February) of $2 \mathrm{mmol} \mathrm{m}^{-2} \mathrm{~h}^{-1}$. At the muddy sand station, M, NPP varied from a maximum of $11 \mathrm{mmol} \mathrm{m}^{-2} \mathrm{~h}^{-1}$ in late summer (August) to a minimum close to 0 in winter (December-February).

Fluxes of $\mathrm{O}_{2}$ measured in dark represent the microbenthic sediment respiration (RSP) by bacteria, microalgae, and micro-, meio- and small macrofauna. The term community respiration is avoided here because larger macrofauna, like Arenicola marina and Mya arenaria, were excluded during incubations. The seasonal variations of RSP were more consistent than those of NPP, with highest rates observed at high temperatures during summer (June-August) and lowest rates during cold winter months (December-February). RSP at the muddy station $M$ varied from summer highs at $3.6 \mathrm{mmol} \mathrm{m} \mathrm{m}^{-2} \mathrm{~h}^{-1}$ to winter lows of $0.7 \mathrm{mmol} \mathrm{m}^{-2} \mathrm{~h}^{-1}$, which was about a factor of 2 higher than at the two sandy stations (1.9-2.2 and 0.2-0.4 $\mathrm{mmol} \mathrm{m}^{-2} \mathrm{~h}^{-1}$ in summer and winter, respectively).

The rates of both microbenthic NPP and RSP obtained here are probably lower than entire community rates as large specimens of the dominating macrofauna and -flora may contribute significantly to the total metabolism (Asmus et al., unpubl.).

Measurements of the dark sediment uptake of $\mathrm{O}_{2}$ when the sediment was exposed to air, simulating a low-tide situation, showed rates similar to the corresponding sedimentwater fluxes (Table 1). Rates were obtained both at low and high temperatures in spring and summer and at both sandy and muddy stations. On average (all stations and both occasions), the sediment-air uptake was 1.13 times the sediment-water uptake. However, when the two most deviating numbers ( $S$ and $M$ in April) are excluded, the average is 1.02.

Daily rates of gross primary production (DGPP) by the microbenthos, as shown in Fig. 6, were estimated as GPP * photosynthetic daylength (Fig. 6). Hourly gross primary

Table 1. Dark low-tide sediment-air (dry) and high-tide sediment-water (wet) uptake of oxygen at the three Königshafen stations in April and June 1993. Data are averages ( \pm S.D.) of 3-5 (dry) and 6 (wet) cores. Rates are in $\mathrm{mmol} \mathrm{m}^{-2} \mathrm{~h}^{-1}$; $\mathrm{nm}$ : not measured

\begin{tabular}{|ccccc|}
\hline & $\mathrm{S}$ & $\mathrm{A}$ & $\mathrm{M}$ \\
\hline \multirow{2}{*}{ April } & - dry & $0.99(0.14)$ & $\mathrm{nm}$ & $2.09(0.31)$ \\
& - wet & $0.73(0.05)$ & $\mathrm{nm}$ & $1.46(0.36)$ \\
June - dry & $2.48(0.33)$ & $1.41(0.47)$ & $3.96(0.55)$ \\
& - wet & $2.54(0.58)$ & $1.23(0.11)$ & $3.95(1.59)$ \\
\hline
\end{tabular}



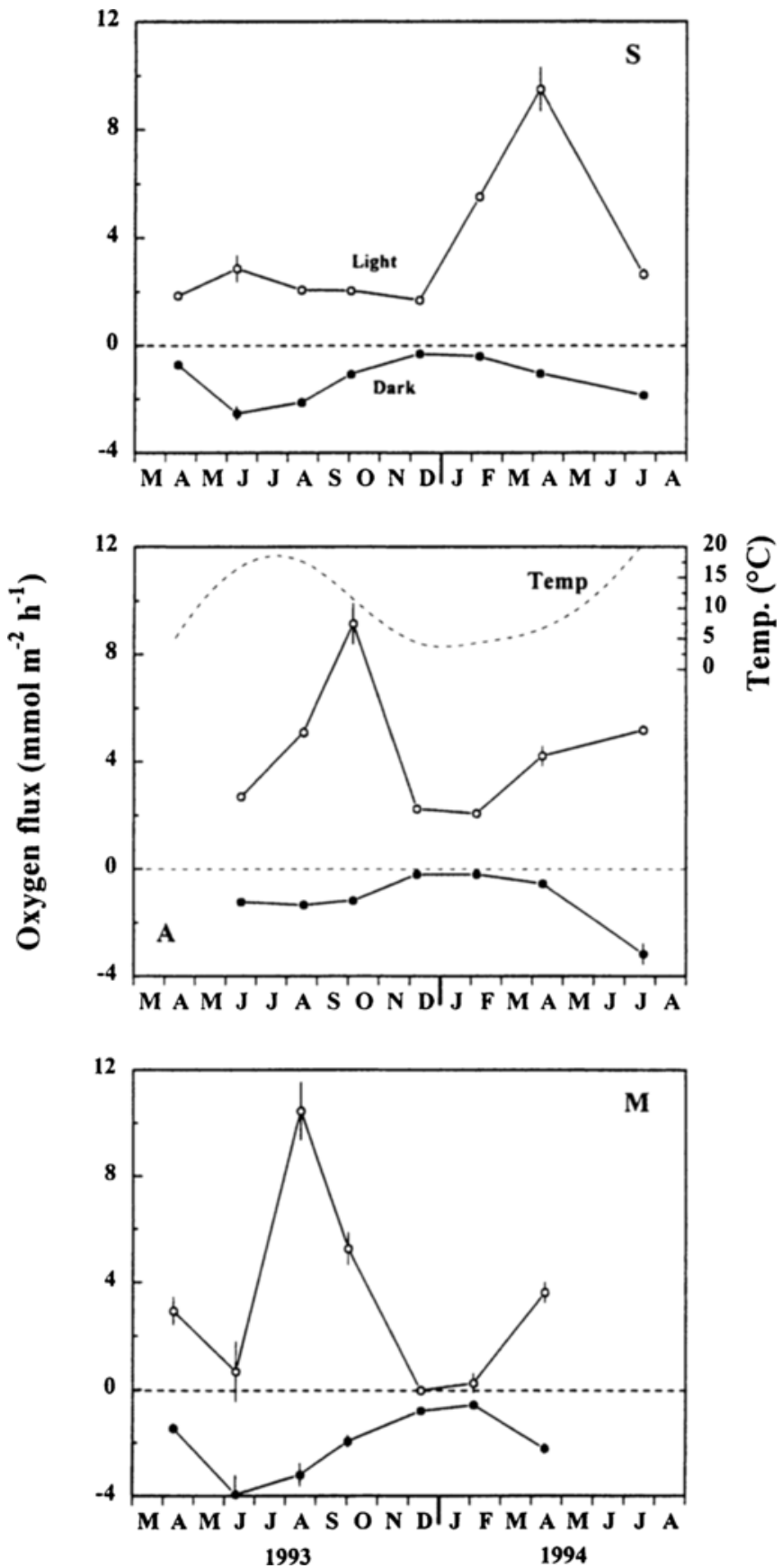

Fig. 5. Seasonal variation in the hourly oxygen fluxes in light (open symbols) and dark (closed symbols) at the 3 Königshafen stations. Data are averages \pm S.E. $(n=4-9)$. Negative values denote uptake by the sediment. Temperature is shown as the broken curve in the middle panel 

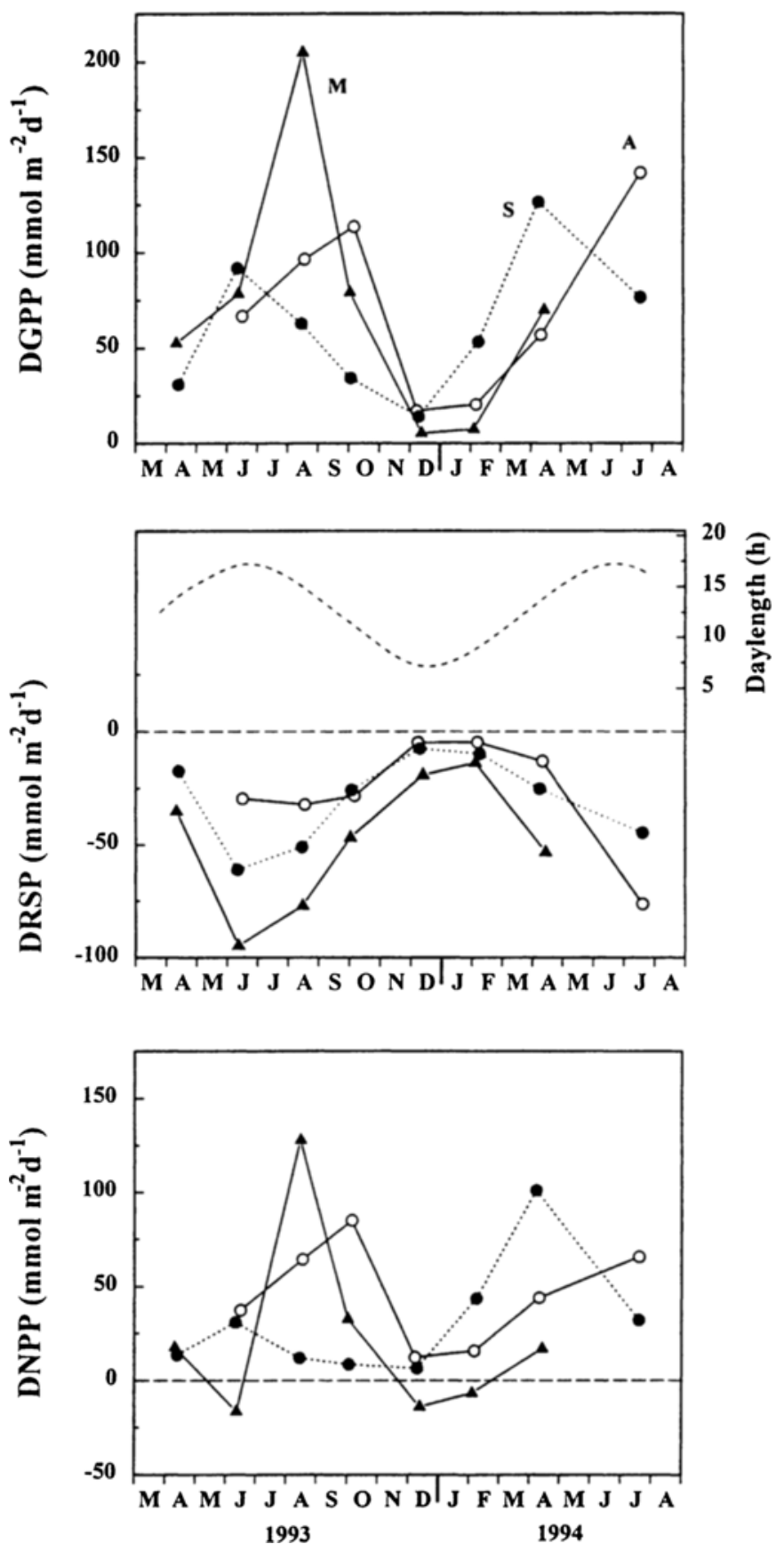

Fig. 6. Seasonal variation in the microbenthic daily gross primary production (DGPP), daily sediment respiration (DRSP) and daily net primary production (DNPP) at the 3 Königshafen stations. Negative values denote uptake by the sediment. Daylength is shown as the broken curve in the middle panel 
production (GPP), which was determined from $\mathrm{O}_{2}$ data as the sum of NPP and RSP, is assumed to be constant throughout the photosynthetic day (defined as the number of hours where the light intensity is higher than the half-saturation level of photosynthesis [Kristensen, 1993]). Daily microbenthic sediment respiration (DRSP) was estimated from the hourly dark fluxes as: DRSP = RSP * 24 h, assuming similar rates in light and darkness (Fig. 6). Daily net primary production (DNPP) was determined as DGPP minus DRSP.

The $\mathrm{CO}_{2}$ fluxes available have been related to the corresponding $\mathrm{O}_{2}$ fluxes to obtain the microbenthic production quotient (MPQ $=\mathrm{O}_{2}$ flux $/ \mathrm{CO}_{2}$ flux) from GPP, and the microbenthic respiration quotient (MRQ $=\mathrm{CO}_{2}$ flux $/ \mathrm{O}_{2}$ flux) from RSP. MRQ was higher during summer (1.08-1.55) than winter (1.05-1.14) with a trend for highest values at $\mathrm{S}$ and lowest values at $\mathrm{M}$ (Table 2). MPQ showed the opposite trend with higher values during winter (0.86-1.33) than during summer (0.57-1.03); highest for $M$ and lowest for $\mathrm{S}$ (Table 2). However, none of these trends were statistically different.

Table 2. Seasonal variations (summer and winter) in microbenthic respiration quotient (MRQ) and microbenthic production quotient (MPQ) in the three Königshafen sites. Values are presented as mean $\pm S$. D. of $n$ determinations

\begin{tabular}{|cccccccccc|}
\hline \multicolumn{3}{c}{ Summer } & \multicolumn{5}{c}{ Winter } \\
\hline & $\mathrm{MRQ}$ & $\mathrm{n}$ & $\mathrm{MPQ}$ & $\mathrm{n}$ & $\mathrm{MRQ}$ & $\mathrm{n}$ & $\mathrm{MPQ}$ & $\mathrm{n}$ \\
$\mathrm{S}$ & $1.55 \pm 0.31$ & 8 & $0.57 \pm 0.10$ & 3 & $1.14 \pm 0.35$ & 5 & $0.86 \pm 0.30$ & 3 \\
$\mathrm{~A}$ & $1.25 \pm 0.17$ & 4 & $0.80 \pm 0.14$ & 3 & $1.08 \pm 0.22$ & 5 & $0.92 \pm 0.14$ & 3 \\
$\mathrm{M}$ & $1.08 \pm 0.15$ & 5 & $1.03 \pm 0.17$ & 3 & $1.05 \pm 0.09$ & 3 & $1.33 \pm 1.40$ & 3 \\
\hline
\end{tabular}

\section{Sediment-water fluxes of dissolved inorganic nitrogen}

The concentration of DIN in the tidal waters of Königshafen varied considerably with season (Fig. 7). $\mathrm{NH}_{4}{ }^{+}$concentration was low during most of the year and varied from a minimum of $1 \mu \mathrm{M}$ in spring, summer and autumn to a maximum of $9 \mu \mathrm{M}$ in winter. For $\mathrm{NO}_{3}^{-}$a more dramatic variation was evident, ranging from minimum concentrations of $<1 \mu \mathrm{M}$ in late summer to a maximum of $60-70 \mu \mathrm{M}$ in winter and early spring.

$\mathrm{NH}_{4}{ }^{+}$fluxes at the sandy stations ( $\mathrm{S}$ and $\mathrm{A}$ ) were mostly directed into the sediment (negative) and were with a few exceptions significantly ( $t$-test, $p<0.05$ ) more negative in light than in darkness (Fig. 8). Efflux of $\mathrm{NH}_{4}{ }^{+}$at these stations was observed only in darkness during warm summer months (July, August). $\mathrm{NH}_{4}{ }^{+}$fluxes at station $\mathrm{S}$ ranged from -80 to $+18 \mu \mathrm{mol} \mathrm{m} \mathrm{m}^{-2} \mathrm{~h}^{-1}$ in the light with effluxes (positive) occurring only in August and September 1993, and from -31 to $+135 \mu \mathrm{mol} \mathrm{m} \mathrm{m}^{-2} \mathrm{~h}^{-1}$ in the dark. The same pattern emerged at station $\mathrm{A}$ as on $\mathrm{S}$, just with slightly more negative $\mathrm{NH}_{4}{ }^{+}$fluxes; from -96 to -20 and -56 to $+53 \mu \mathrm{mol} \mathrm{m}^{-2} \mathrm{~h}^{-1}$ in the light and dark, respectively. It should also be noted here, however, that particularly at station A the direct impact of Arenicola marina on especially $\mathrm{NH}_{4}{ }^{+}$effluxes was not included during flux measurements. The sedimentwater exchange of $\mathrm{NH}_{4}{ }^{+}$at the muddy station $\mathrm{M}$ was quite different from that at the sandy 


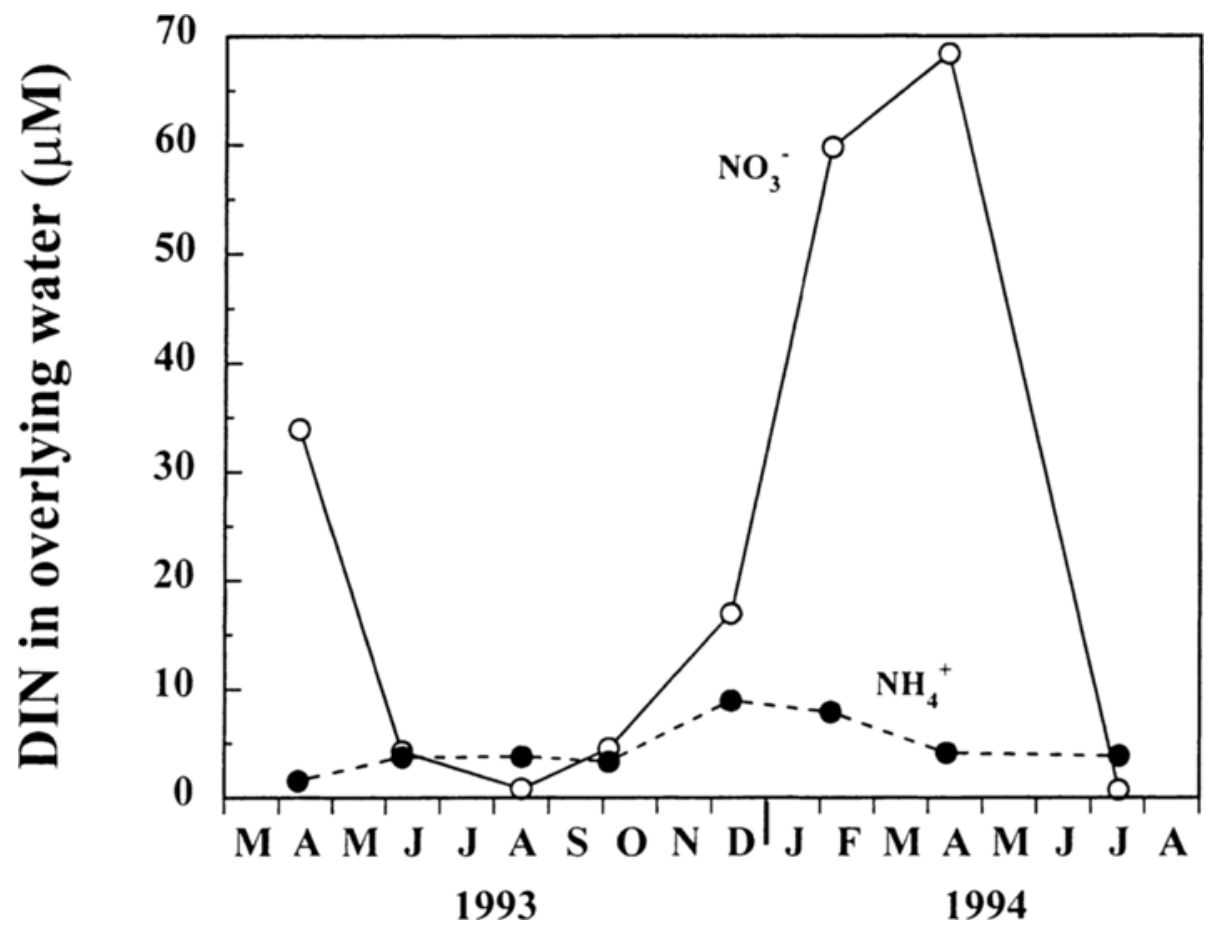

Fig. 7. Seasonal variation in ammonium and nitrate in the tidal water of Königshafen

stations (Fig, 8). Rates were generally higher and consistently directed out of the sediment in both light and darkness (except for one occasion with a low uptake), ranging between about 0 to $+150 \mu \mathrm{mol} \mathrm{m} \mathrm{m}^{-2} \mathrm{~h}^{-1}$, with slightly, but not significant $(\mathrm{p}>0.05)$ higher release in the dark.

$\mathrm{NO}_{3}{ }^{-}$fluxes were low at all three stations in both light and darkness during summer, while peaks of $\mathrm{NO}_{3}^{-}$uptake were observed in winter and early spring (Fig. 9). Despite the low overlying water concentrations, $\mathrm{NO}_{3}{ }^{-}$was consistently taken up during summer, with only a few exceptions at the sandy stations. Full ranges for the three stations in light (L) and darkness (D) were, S: -492 to +11 (L) and -161 to +2 (D) $\mu \mathrm{mol} \mathrm{m}{ }^{-2} \mathrm{~h}^{-1}$; A: -220 to +26 (L) and -61 to +11 (D) $\mu \mathrm{mol} \mathrm{m}^{-2} \mathrm{~h}^{-1}$; and $\mathrm{M}$ : -202 to -8 (L) and -176 to -7 (D) $\mu \mathrm{mol} \mathrm{m} \mathrm{m}^{-2} \mathrm{~h}^{-1}$. There was no difference in flux pattern between sand and mud, and when the very high uptake at $\mathrm{S}$ in April is excepted, the maximum uptake at all stations in spring 1993 and 1994 was about $200 \mu \mathrm{mol} \mathrm{m}{ }^{-2} \mathrm{~h}^{-1}$. The $\mathrm{NO}_{3}^{-}$uptake was generally higher $(p<0.05$ for $S$ and $A$, and $p>0.05$ for $M$ ) in light than in darkness during periods of high rates (April), whereas no significant difference $(p>0.05)$ was observed during periods with low rates.

The total DIN fluxes $\left(\mathrm{NH}_{4}{ }^{+}+\mathrm{NO}_{3}{ }^{-}\right)$were estimated from dark and light measurements as hourly gross fluxes: GDIN; dark fluxes: RDIN; and net fluxes: NDIN (Fig. 10) as mentioned for $\mathrm{O}_{2}$ earlier (GDIN = NDIN (flux in light) - RDIN (flux in darkness)). The hourly DIN fluxes were mostly directed into the sediment, except for occasional efflux, 

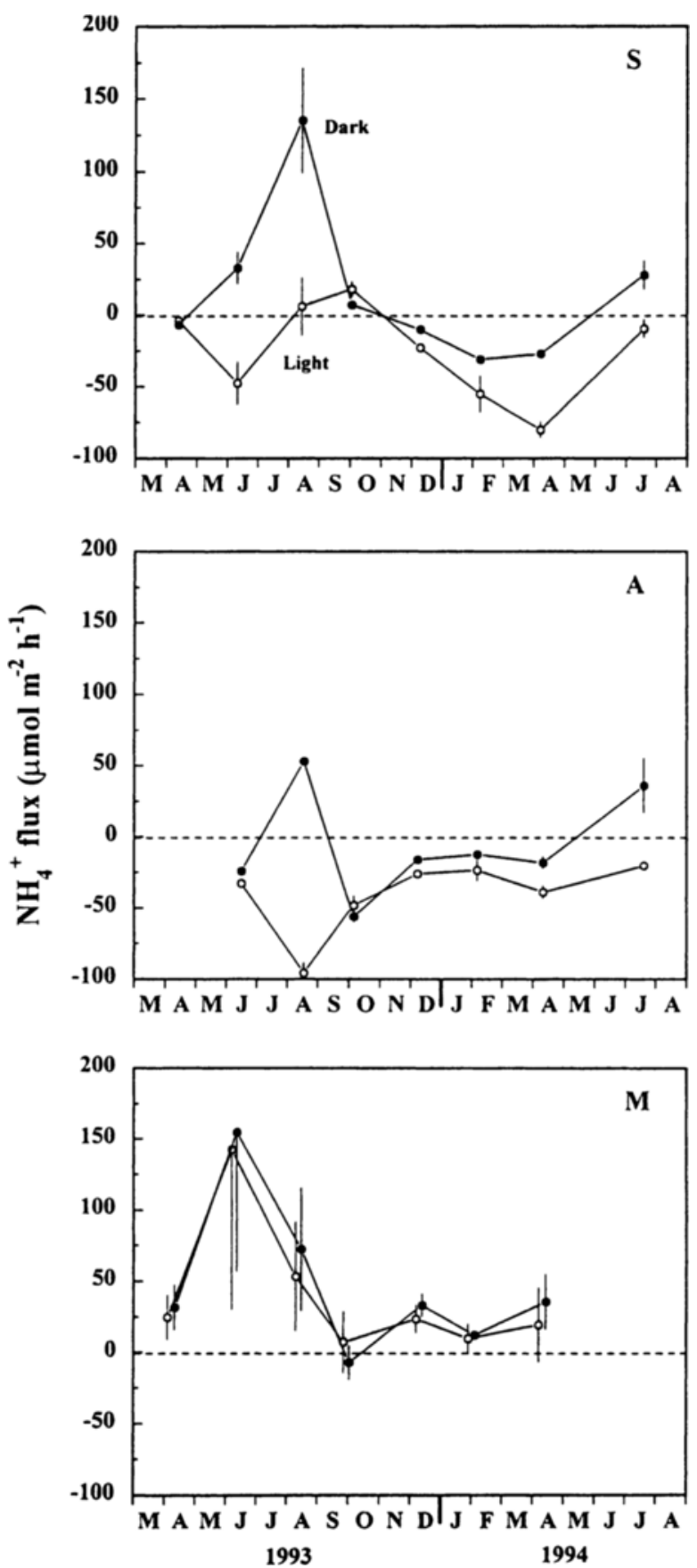

Fig. 8. Seasonal variation in hourly ammonium fluxes in light (open symbols) and dark (closed symbols) at the 3 Königshafen stations. Data are averages \pm S.E. $(n=4-9)$. Negative values denote uptake by the sediment 

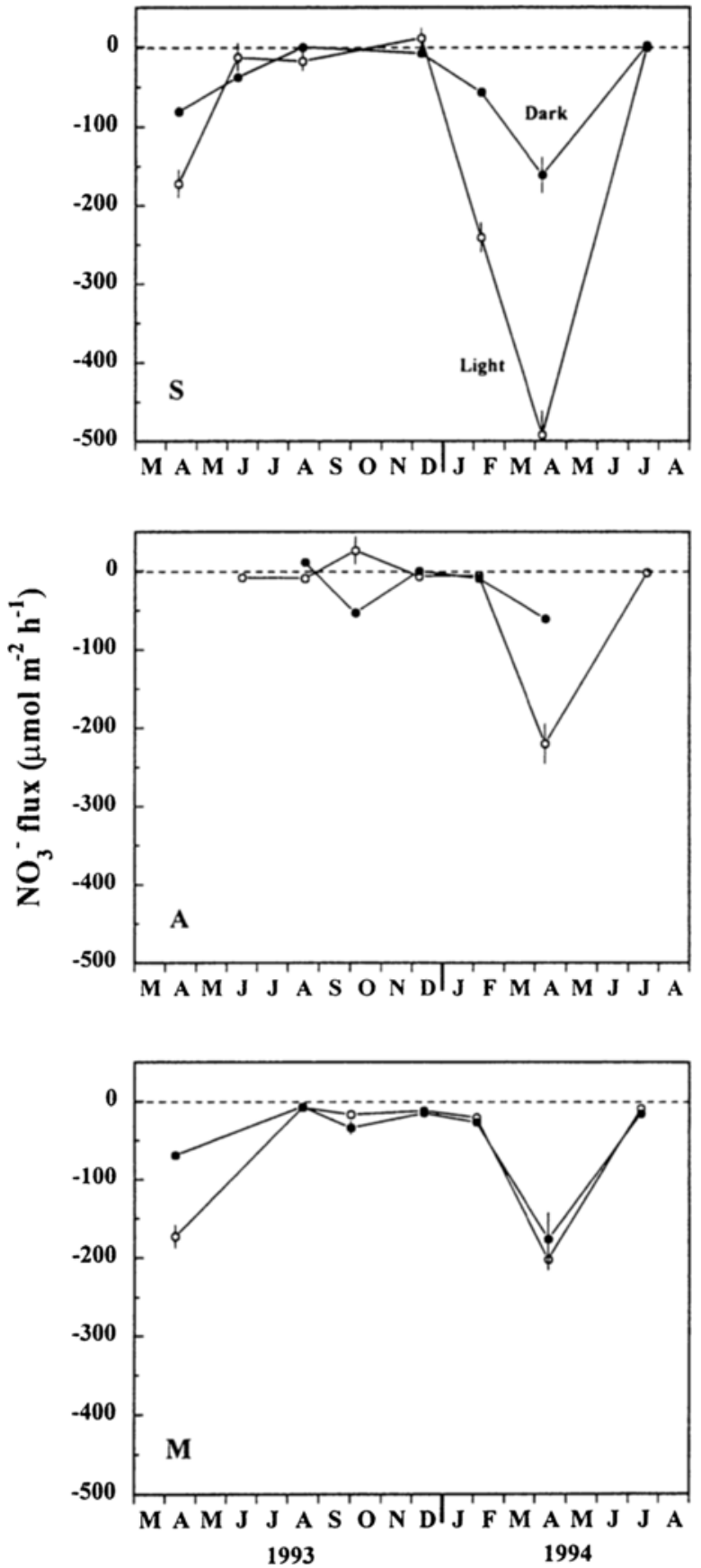

Fig. 9. Seasonal variation in hourly nitrate fluxes in light (open symbols) and dark (closed symbols) at the 3 Königshafen stations. Data are averages \pm S.E. $(n=4-9)$. Negative values denote uptake by the sediment 
especially in the period August to October (Fig. 10). Otherwise, GDIN, RDIN and NDIN showed almost similar seasonal patterns. The seasonal variations were most dramatic for NDIN at station S and least for RDIN at station $M$.

\section{DISCUSSION}

\section{Methodological considerations}

The core-flux incubations presented here do not mimic actual in situ conditions of the highly fluctuating environment in Königshafen, i.e. waves, tides, currents, diurnal and day-to-day changes in light, temperature and nutrient concentrations. For comparative purposes, we deliberately held cores at constant temperature during each 1-2 week sampling period, and near-saturating light and overlying water movement at all occasions. This is opposed to, for example, bell jar measurements (e.g. Asmus, 1986) and core measurements (e.g. Grant, 1986), where incubations are carried out at prevailing temperature and light conditions. Although differences between fluxes obtained by the latter approaches in the Wadden Sea and our laboratory core experiments occur, the general pattern and flux rates of $\mathrm{O}_{2}$ and DIN are of similar and comparable magnitude (van Es, 1982; Hargrave et al., 1983; Henriksen et al., 1984; Asmus \& Asmus, 1985; Therkildsen \& Lomstein, 1993). However, flux rates obtained by the use of large-scale flumes and similar constructions, which enclose entire sub-systems under the influence of all prevailing physical and chemical factors, may differ considerably (Asmus et al., in prep). The rates and relationships presented here should therefore be considered as small-scale sediment-water interactions related predominantly to the microbial community (including small animals), and should not be extrapolated to represent larger Wadden Sea systems.

\section{Microbenthic primary production and respiration}

A variety of physical, chemical and biological factors are known to control the rates and seasonal variation of benthic primary production, respiration and nutrient dynamics in coastal areas (Davis \& McIntire, 1983; Grant, 1986; Sampou \& Oviatt, 1991; Kristensen, 1993). However, interpretations are restrained by the fact that various factors may control benthic metabolism at different times during the annual cycle. Furthermore, the high temporal and spatial variability in the strength of physical forces (e.g. storms and tides) and thus resuspension of surface sediment in Wadden Sea areas complicates a factorial analysis (de Jonge \& van Beusekom, 1995). However, based on the pairwise correlations in Table 3 , we will discuss and compare a number of important seasonal factors of obvious relevance for microbenthic metabolism at our 3 representative sediment systems in the Königshafen Wadden Sea area.

The seasonal variation of DGPP at the 3 Königshafen stations (Fig. 6) is within the range previously reported from the Wadden Sea (Colijn \& van Buurt, 1975; van Es, 1982; Rasmussen et al., 1983; Colijn \& de Jonge, 1984). According to these studies, the annual primary production cycle can be explained largely by seasonal changes in temperature and daylength. In the present study, the relationship between DGPP and daylength is trivial, since DGPP actually was determined as GPP corrected for daylength. GPP 

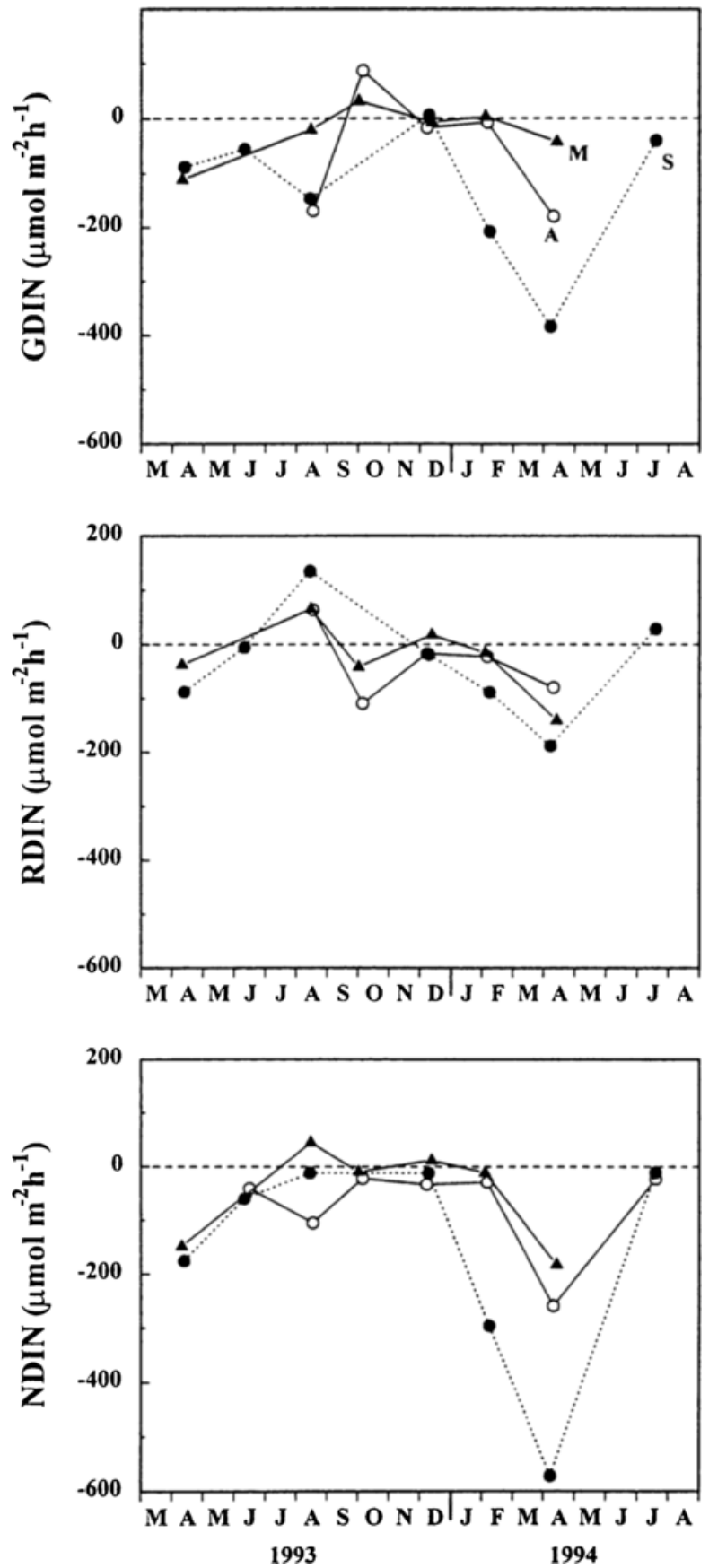

Fig. 10. Seasonal variation in hourly gross DIN uptake (GDIN = flux in dark - flux in light), hourly dark DIN flux (RDIN) and hourly net DIN flux (NDIN) at the 3 Königshafen stations. Negative values denote uptake by the sediment 
Table 3. Pairwise Pearson correlation table ( $\mathrm{r}$ ) between hourly rates of the four flux parameters, benthic gross primary production (GPP), benthic sediment respiration (RSP), gross dissolved inorganic nitrogen uptake (GDIN) and dark dissolved inorganic nitrogen flux (RDIN) at the three Königshafen stations. In addition the correlation is given between these four parameters and water temperature (temp), organic content (LOI) in the upper $0.5 \mathrm{~cm}$ of the sediment, chlorophyll a (Chl) in the upper $0.5 \mathrm{~cm}$ of the sediment, concentration of DIN in the overlying water $\left(D N_{o v}\right)$. Significant relationships $(p<0.05)$ are indicated by ${ }^{*}$

\begin{tabular}{|c|c|c|c|c|c|c|c|c|c|c|c|c|}
\hline & \multicolumn{4}{|c|}{$\mathrm{S}$} & \multicolumn{4}{|c|}{ A } & \multicolumn{4}{|c|}{$\mathrm{M}$} \\
\hline & GPP & RSP & GDIN & RDIN & GPP & RSP & GDIN & RDIN & GPP & RSP & GDIN & RDIN \\
\hline RSP & -0.14 & - & - & - & -0.66 & - & - & - & -0.65 & - & - & - \\
\hline GDIN & $-0.89^{*}$ & -0.10 & - & - & 0.46 & -0.40 & - & - & 0.03 & -0.10 & - & - \\
\hline RDIN & -0.58 & -0.50 & 0.57 & - & -0.02 & -0.53 & 0.44 & - & 0.13 & -0.54 & -0.32 & - \\
\hline Temp & -0.04 & $-0.90^{*}$ & 0.28 & 0.61 & 0.61 & $-0.88^{*}$ & 0.29 & 0.68 & $0.78^{\circ}$ & $-0.90^{*}$ & -0.15 & 0.63 \\
\hline LOI & 0.59 & $-0.69^{\circ}$ & -0.36 & 0.04 & 0.42 & -0.45 & $0.72^{*}$ & 0.48 & 0.44 & $-0.86^{*}$ & -0.52 & 0.49 \\
\hline Chl & -0.66 & 0.53 & 0.47 & -0.20 & $0.68^{*}$ & -0.01 & $0.82^{*}$ & 0.03 & $0.98^{*}$ & $-0.97^{*}$ & -0.03 & 0.33 \\
\hline $\mathrm{DIN}_{u v}$ & 0.63 & 0.48 & $-0.79^{*}$ & $-0.81^{*}$ & -0.56 & 0.63 & $-0.80^{*}$ & $-0.73^{*}$ & -0.50 & 0.55 & 0.19 & $-0.69^{*}$ \\
\hline
\end{tabular}

appeared to be temperature dependent with a 'seasonal $\mathrm{Q}_{10}$ ' around 1.7-1.8 as previously reported (Colijn \& van Buurt, 1975; Rasmussen et al., 1983; Kristensen, 1993). It should be noted here that the term 'seasonal $Q_{10}$ ' is more appropriate for sediment systems than the physiologically defined ' $Q_{10}$ ', because it also includes changes in, for example, microbial populations and environmental parameters (Moeslund et al., 1994). In fact, the poor correlation between GPP and temperature (Table 3) at the two sandy sites suggests that the controlling mechanisms are related to other factors as well. It is evident that at the coarse sand site, the GPP peak in 1994 (no peak in 1993) was displaced to the relatively cold spring period, while at the fine sand site the peak occurred in autumn when temperatures were decreasing (Fig. 5). A similar seasonal pattern of GPP has previously been observed at the same two locations (Asmus \& Asmus, 1985). Temperature appeared to be a significant controlling factor for GPP at the muddy site (Table 3), while overall control at the two sandy sites seems more complex due to simultaneous influence of biotic (e.g. grazing) and chemical (e.g. nutrient availability) factors.

The negative (although not significant) relationship between GPP and surface chlorophyll $a$ at the coarse sand site (Table 3 ) suggests that grazing by the small mudsnail Hydrobia ulvae was important during spring and summer, thus causing the poor temperature dependence of GPP. Similar impact of Hydrobia spp. and other benthic grazers has previously been reported (Connor et al., 1982; Hargrave et al., 1983; Asmus \& Asmus, 1985; Kristensen, 1993). It is generally accepted that at low grazing pressures there is a positive feedback on microalgal biomass, while a negative feedback occurs above a certain threshold (Hargrave et al., 1983; Andersen \& Kristensen, 1988). At the coarse sand site, mudsnail grazing pressure must increase during spring (especially 1994) in concert with increasing temperatures and snail population density, resulting in a positive feedback, but during summer the grazing pressure is too intensive and results in a negative feedback. 
The poor temperature dependence of GPP at the fine sand site is probably not caused by grazing macrofauna, as evidenced by a significant positive relationship between GPP and surface chlorophyll a (Table 3). However, nutrient limitation may have occurred during summer at this site, since efflux of DIN from the sediment at this site was hardly ever observed even in the dark (Figs 8-10). Studies from intertidal areas have demonstrated that nutrient supply may temporally be a principal factor limiting benthic primary production (Sundbäck et al., 1991; Kristensen, 1993). Furthermore, Rasmussen et al. (1983) postulated that $\mathrm{CO}_{2}$ can limit microphytobenthic primary production in Wadden Sea sediments during periods of high light intensity due to photosynthetically induced high $\mathrm{pH}$ in surface porewaters. Nevertheless, the interpretation of the core data at the fine sand site is complicated by the lack of the otherwise dominating faunal component, the lugworm Arenicola marina (Cadée, 1976).

At the muddy site, where no diatom grazers were present (positive relationship between GPP and surface chlorophyll $a$, Table 3) and sufficient nutrient supplies were available from the sediment below (consistent efflux of DIN from the sediment during summer), temperature seems to control GPP as indicated by a significant correlation (Table 3). The positive relationship with GPP, though, infers that chlorophyll a concentration in surface sediment at the two subtidal stations ( $A$ and $M$ ) could be a co-factor for the control of benthic primary production, as also suggested for a variety of sediments in the Dutch Wadden Sea (Colijn \& de Jonge, 1984).

The specific productivity of the microalgae ( $\mathrm{mg} \mathrm{C}[\mathrm{mg} \mathrm{chl.} \mathrm{a}]^{-1} \mathrm{~h}^{-1}$ ), estimated by converting $\mathrm{O}_{2}$ fluxes to carbon by the use of MPQ's (Table 2), seems to follow the same seasonal pattern at all 3 locations with low values during winter (0.1-0.3) and high values during summer $(0.8-0.9)$. Similar patterns from other areas have been ascribed to a strong temperature dependence of specific productivity (Colijn \& van Buurt, 1975), although it also has been suggested that the high specific activity during summer is caused by grazing pressure which reduces microalgal biomass, but keeps the algal cells active (Davis \& Lee, 1983; Kristensen, 1993).

The rates and seasonal pattern of sediment respiration (DRSP) at the 3 Königshafen sites (Fig. 6) are similar to those previously observed in the Wadden Sea (van Es, 1982; Andersen \& Helder, 1987). As RSP measured as oxygen flux is almost identical with and without water cover, the inundation frequency can be ignored in estimates of DRSP. In accordance with previous studies (van Es, 1982; Hargrave et al., 1983; Kristensen, 1993), a highly significant correlation (Table 3 ) indicates that sediment respiration in Königshafen sediments is controlled largely by temperature with a 'seasonal $\mathrm{Q}_{10}$ ' of 2.7-4.3. However, the relationship between RSP and temperature can be misleading, since factors correlated with temperature, such as supply of organic matter may also control heterotrophic activity (Hargrave et al., 1983; Sampou \& Oviatt, 1991). In fact, the seasonal variation in organic matter correlates with RSP, although only significantly at the coarse sand and the muddy sand sites (Table 3).

The seasonal variation in organic content is only partly caused by the variation in microphytobenthic biomass. The annual range of microalgal biomass in the upper $0.5 \mathrm{~cm}$ of the sediment, estimated from an organic carbon:chlorophyll a ratio of 40 (de Jonge, 1980 ), varies from $227-305 \mathrm{mmol} \mathrm{C} \mathrm{m}^{-2}$ in winter to $264-583 \mathrm{mmol} \mathrm{C} \mathrm{m}^{-2}$ in summer. Thus, the standing crop only accounts for $10-20 \%$ of the total organic carbon in the upper $0.5 \mathrm{~cm}$ at the coarse sand site (S), about $18 \%$ at the fine sand site (A) and $7-14 \%$ at the 
muddy sand site (M). This is within the range of previously reported values from intertidal sandy sediments (Cammen, 1991; Kristensen, 1993). However, only 0-10\% of the seasonal variation in total organic carbon can be accounted for by changes in microphytobenthic biomass. The remainder of the variation in organic content at the sediment surface must, especially at the muddy sand site, be caused by enhanced deposition of allochthonous detritus during calm spring and summer months and resuspension and export during stormy autumn and winter months (Cadée \& Hegeman, 1977; de Jonge \& van Beusekom, 1995; de Jong \& de Jonge, 1995).

Although allochthonous detritus is usually considered less reactive on a weight specific basis than freshly produced microphytobenthic biomass (Kristensen, 1993), the much higher content of detritus at the muddy site must be responsible for the generally higher RSP at this station. On the other hand, it is also evident that the much larger seasonal variation in bulk organic content at the muddy site does not enhance RSP in the same proportion as at the two sandy sites (Fig. 11). Accordingly, the allochthonous organic matter being deposited during spring and summer at the muddy site is of another origin (Bayerl et al., 1996) and probably less degradable than at the sandy sites. We have observed that the muddy site is a deposition area for partly degraded drifting macroalgae and seagrass detritus, while the sandy sites, in accordance with other Wadden Sea areas (de Jonge \& van Beusekom, 1995), primarily receive planktonic and resuspended organic debris of microalgal origin.

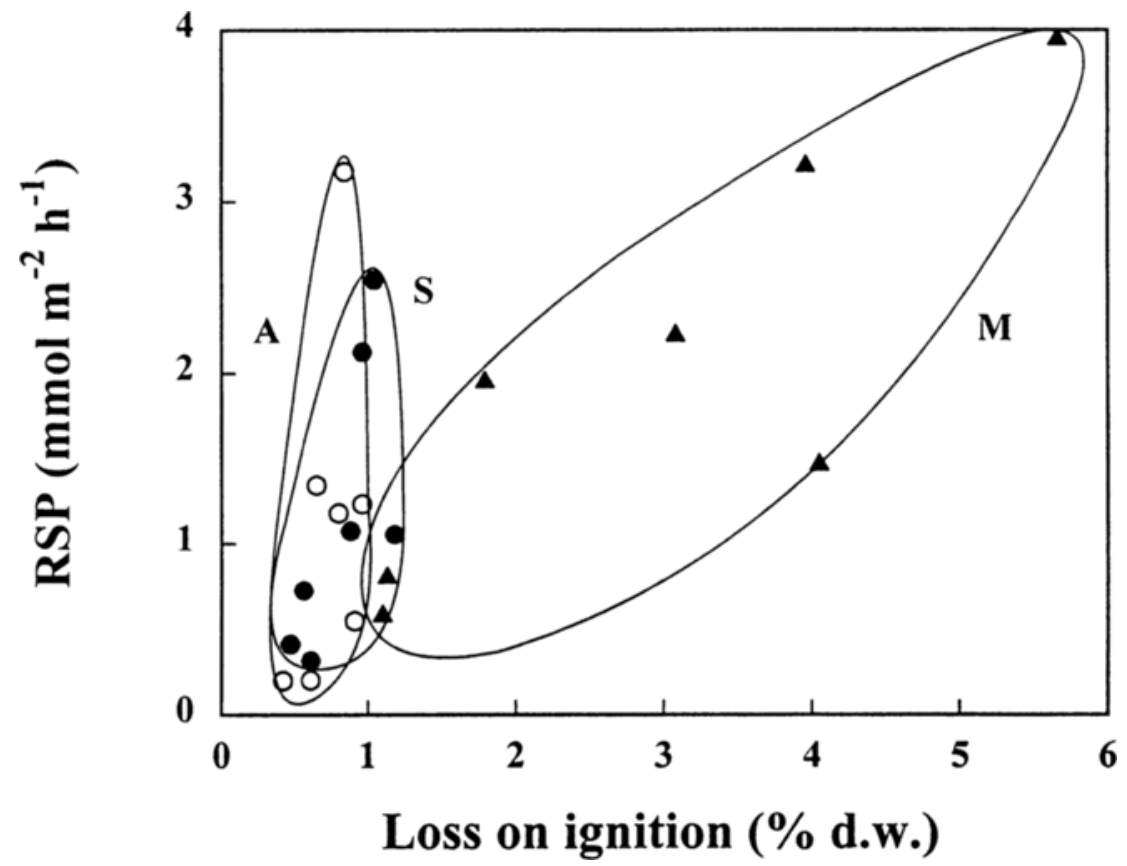

Fig. 11. The relationship between hourly microbenthic sediment respiration and organic content in the upper $3 \mathrm{~mm}$ of the sediment at the 3 Königshafen stations 


\section{Dissolved inorganic nitrogen fluxes}

The microphytobenthos influences nutrient fluxes both directly through assimilation from water and sediment, and indirectly by affecting the oxygen penetration into sediments by photosynthesis and respiration. In most intertidal sediments, a close coupling occurs between DIN consumption by benthic microalgae and mineralization by microheterotrophs in the upper part of the sediment (e.g. Nowicki \& Nixon, 1985b; Kristensen, 1993). In the Danish Wadden Sea, Henriksen et al. (1984) found that benthic microalgal activities effectively prevented ammonium from leaving the sediment ('filter effect'). Even though a similar coupling must also occur in the present Wadden Sea sediment, it could not be unequivocally confirmed by the present data, since fluxes were generally directed into the sediment both in light and darkness (Figs 8-9).

The hourly gross primary production in the present study (GPP) is significantly related to gross uptake of dissolved inorganic nitrogen (GDIN, Fig. 10, Table 3) in the high intertidal coarse sand. However, the measured GDIN could only support between 10 and $40 \%$ of the microphytobenthic DIN demand (assuming that carbon and nitrogen are incorporated in a molar ratio of 7 ; Parsons et al., 1961). At the low intertidal sand and mud sites no correlation between GPP and GDIN was evident, and only 2-60\% and 0-18\% of the DIN demand, respectively, could be covered by the measured GDIN.

The low contribution of GDIN and displaced seasonal variation relative to GPP are puzzling, since GDIN is calculated similarly to and thus should correspond to the GPP estimate. Beside temporal variations in nitrogen assimilation and possibly higher $\mathrm{C}: \mathrm{N}$ ratios than 7 for microalgae (Eppley, 1981; Sundbäck \& Graneli, 1988), an explanation for the missing DIN could be that the pre-incubation period before initiating the dark incubation was too short for obtaining the true dark DIN flux (RDIN). Several studies have shown that benthic microalgae have a continued DIN demand for 24 hours or more after onset of darkness (Andersen \& Kristensen, 1988; Rysgaard et al., 1993), resulting in an underestimate of GDIN. "True" dark fluxes (i.e. free from microphytobenthic interference) may for that reason be a redundant term in intertidal sediments when benthic diatoms are present. The effect probably changes from season to season and from muddy to sandy sites, and is dependent on factors such as availability of $\mathrm{NO}_{3}{ }^{-}$and $\mathrm{NH}_{4}{ }^{+}$, and the population status of the microphytobenthos. This is substantiated by the lack of any significant relationship between RSP and RDIN on a seasonal basis, together with a generally negative RDIN. Another problem, which can seriously affect both GDIN and RDIN estimates, is the role of nitrification and denitrification. A variety of studies have emphasized that denitrification causes the C:N ratio of dark sediment-water fluxes to be higher and thus not representative for the reaction stoichiometry within the sediment (Jensen et al., 1990; Kristensen \& Hansen, 1995). In a parallel study, however, Jensen et al. (1996) found that denitrification in darkness at the 3 Königshafen sites accounted on average for only $18 \%$ of the total dark $\mathrm{NO}_{3}{ }^{-}$uptake. Furthermore, it has recently been shown that the rate of denitrification may vary between light and darkness depending on oxygen penetration and overlying nitrate concentration (Rysgaard et al., 1995).

On a seasonal basis, the DIN concentration in the overlying water (DIN $N_{O V}$ ) is an important controlling factor for DIN fluxes (RDIN and NDIN ) at all three Königshafen stations (Table 3). A typical feature of the Wadden Sea is the highly variable concentrations of DIN and particularly $\mathrm{NO}_{3}{ }^{-}$in incoming North Sea water throughout the annual 
cycle (Fig. 7), with highest concentrations in late winter and early spring and lowest during summer (Hickel, 1989). The source of GDIN apparently varies between overlying water and underlying porewaters depending on the availability of DIN. Accordingly, GDIN was dominated by $\mathrm{NH}_{4}{ }^{+}$in summer and autumn when $\mathrm{NO}_{3}{ }^{-}$concentrations in the overlying water were low, and by $\mathrm{NO}_{3}{ }^{-}$from the high concentrations in winter and spring.

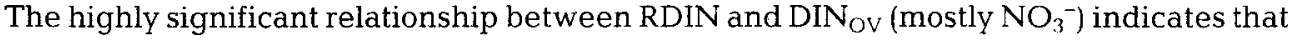
the dark flux was driven by the steepness of the gradient from overlying water to the sediment, and thus the $\mathrm{NO}_{3}^{-}$reducing capacity of the sediment (microalgal assimilation and denitrification). At the 3 Königshafen stations, Jensen et al. (1996) found that about $70 \%$ of the annual mean dark denitrification was due to $\mathrm{NO}_{3}{ }^{-}$from the overlying water, and that denitrification was generally proportional to the $\mathrm{NO}_{3}{ }^{-}$concentration in the overlying water.

\section{Annual budgets}

The results from the present study should not be extrapolated to the entire Königshafen area for two major reasons. First, the full range of the physical regime and spatial heterogeneity is not included. Second, the larger macroscopic components are ignored as only the microbenthic contribution is considered. However, when considering only the spatial scale of the present incubations, an annual budget of carbon and nitrogen can be made for comparative purposes. The following annual budgets (Table 4 ) are based on integrations of the daily $\mathrm{CO}_{2}$ data (converted from $\mathrm{O}_{2}$ ) with the assumptions that the hourly net flux of $\mathrm{CO}_{2}$ is independent of tides, and the net flux of DIN is 0 at low tide.

Annual microbenthic gross primary production (AGPP) at the coarse sand station (S) was about 10 and $50 \%$ higher than at the fine sand (A) and the mud (M) station (Table 4). As expected, the annual microbenthic respiration (ARSP) was highest in the mud, about twice as high as in the sands. Consequently, annual net primary production (ANPP) was almost 0 in the mud, whereas rates of $17-19 \mathrm{~mol} \mathrm{C} \mathrm{m}^{-2} \mathrm{yr}^{-1}$ was evident at the two sandy sites. In an oligotrophic, organic-poor Danish lagoon, Kristensen (1993) found values of AGPP and ARSP (15 and $12 \mathrm{~mol} \mathrm{~m}^{-2} \mathrm{yr}^{-1}$, respectively) comparable to those obtained here. The basic assumption that $\mathrm{CO}_{2}$ fluxes are similar with and without water cover is supported by the fact that dark $\mathrm{O}_{2}$ uptake (and probably also in light) is independent of

Table 4. Annual rates ( $\mathrm{mol} \mathrm{m} \mathrm{m}^{-2}$ year $^{-1}$ ) of microbenthic gross primary production (AGPP), respiration (ARSP), net primary production (ANPP), gross DIN $\left(\mathrm{NH}_{4}{ }^{+}+\mathrm{NO}_{3}{ }^{-}\right.$) flux (AGDIN), dark DIN flux (ARDIN) and net DIN flux (ANDIN) at the three Königshafen stations in 1993-94. AGPP, ARSP and ANPP are presented in carbon units by converting from $\mathrm{O}_{2}$ data using appropriate average MPQ and $M R Q$ values (Table 2). The estimates are based on integrations of the daily data, where it is assumed that the hourly net flux of $\mathrm{CO}_{2}$ is independent of tides, whereas the net flux of DIN species is 0 at low tide (DIN values should be multiplied by $3(\mathrm{~S}), 1.8(\mathrm{~A})$ and $2.2(\mathrm{M})$ if this assumption is not

used). Positive and negative values denote release from and uptake by sediment, respectively

\begin{tabular}{|c|c|c|c|c|c|c|}
\hline & AGPP & ARSP & ANPP & AGDIN & ARDIN & ANDIN \\
\hline S & 30.6 & 13.5 & 17.1 & -0.18 & -0.08 & -0.26 \\
\hline $\mathrm{A}$ & 28.0 & 9.3 & 18.7 & -0.10 & -0.13 & -0.23 \\
\hline $\mathrm{M}$ & 20.1 & 20.0 & 0.1 & -0.03 & -0.04 & -0.07 \\
\hline
\end{tabular}


inundation in Wadden Sea sediments (Table 1). Previous studies have concluded that the exchange of $\mathrm{O}_{2}$ between sediment and air (low tide) corresponds to the exchange between sediment and water (high tide) when the surface topography is relatively smooth as in most Wadden Sea sediments (Grant, 1986; Kristensen et al., 1992, 1994). However, Bodenbender \& Papen (1996) found rates of dark $\mathrm{CO}_{2}$ emission from exposed Königshafen sediments around $50 \%$ lower than the dark $\mathrm{O}_{2}$ uptake measured here. Although tentative, as these data were not obtained at the same sites at the same time with the same incubation equipment, the lower $\mathrm{CO}_{2}$ emissions from exposed sediment may not reflect a lower benthic metabolism, but instead the complex diffusion and dissolution/precipitation properties of the ' $\mathrm{CO}_{2}$ system' and possibly an accumulation of $\mathrm{CO}_{2}$ in the porewaters (Boudreau, 1987). Anyway, until more is known, sediment respiration is assumed to be similarly irrespective of inundation status.

Based on the annual carbon estimates, the sandy sites are net-autotrophic, whereas the muddy site is in balance between autotrophy and heterotrophy. It seems unlikely that habitats in Königshafen are net-autotrophic on an annual scale. However, not included here are the heterotrophic contribution of large specimens of e.g. Arenicola marina and certain habitat types, e.g. mussel beds (Andersen \& Kristensen, 1988; Asmus \& Asmus, 1996), and physical removal (and deposition) of organic carbon caused by, for example, winds, tides and currents (Bayerl et al., 1996), which can be important and probably balance the budgets. Furthermore, export of carbon via crab, fish and bird predation should also be considered (Raffaeli \& Milne, 1987; Hall et al., 1990; Thrush et al., 1994).

All three studied sites appeared to be net sinks for dissolved inorganic nitrogen (DIN) on an annual basis. The uptake of DIN both in light and darkness was much lower at the muddy than at the two sandy sites (Table 4). There seems to be a serious annual deficiency of DIN, as the $C: N$ ratio of gross rates, AGPP/AGDIN $=170-670$, was much higher than the 7-10 expected for microphytobenthos (Sundbäck \& Graneli, 1988). Even the annually integrated dark rates (ARDIN) were directed into the sediment, rendering any $\mathrm{C}: \mathrm{N}$ estimate for net mineralization impossible. The cause for these discrepancies is probably due to the simplifying assumption that rates of DIN exchange are constant throughout day and night periods (Rysgaard et al., 1993), given the interactions between the "filter effect" of microphytobenthic DIN assimilation, nitrification and denitrification occurring in surface sediment, and changes in DIN concentrations in the water phase. The assumption that DIN fluxes are 0 during low tide and constant during high tide may also be biased because an accumulation or depletion of a compound in the porewater during low tide may be compensated by an increased or decreased initial flux during water cover (Gardner, 1973; Camacho-Ibar \& Alvarez-Borrego, 1988).

Acknowledgements. We thank Hanne Brandt, Susan Andreassen, Kim D. Kristiansen, Bente F. Jacobsen and Gary T. Banta for invaluable assistance during field and laboratory work. Our gratitude is also due to the staff at Wattenmeerstation Sylt for hospitality and patience during our investigations in the field. This study, funded by the Federal Ministry of Research (BMBF) in the frame of SWAP ("Sylter Wattenmeer Austausch Prozesse"), is publication no. 272 of the project "Ecosystem Research Wadden Sea". 


\section{LITERATURE CITED}

Admiraal, W. \& Peletier, H., 1980. Influence of temperature and light on the growth rate of cultures and natural populations of intertidal diatoms. - Mar. Ecol. Prog. Ser. 2, 35-43.

Andersen, F. $\varnothing$. \& Helder, W., 1987. Comparison of oxygen microgradients, oxygen flux rates and electron transport system activity in coastal marine sediments. - Mar. Ecol. Prog. Ser. 37, 259-264.

Andersen, F. Ø. \& Kristensen, E., 1988. The influence of macrofauna on estuarine benthic community metabolism: a microcosm study. - Mar. Biol. 99, 591-603.

Armstrong, F. A., Stearns, C. R. \& Strickland, J. D. H., 1967. The measurement of upwelling and subsequent biological processes by means of the Technicon Auto-analyzer and associated equipment. - Deep-Sea Res. 14, 381-389.

Asmus, R., 1986. Nutrient flux in short-term enclosures of intertidal sand communities. - Ophelia 26, $1-18$.

Asmus, H. \& Asmus, R., 1985. The importance of grazing food chain for energy flow and production in three intertidal sand bottom communities of the northern Wadden Sea. - Helgoländer Meeresunters. 39, 273-301.

Asmus, R. \& Asmus, H., 1996. Bedeutung der Organismengemeinschaften für den bentho-pelagischen Stoffaustausch. In: SWAP - Sylter Wattenmeer Austauschprozesse - Projektsynthese. Boysen, Tönning, 213-251.

Austen, I., 1994. The surficial sediments of Königshafen - variations over the past 50 years. - Helgoländer Meeresunters. 48, 163-171.

Backhaus, J., Hartke, D., Hübner, U., Lohse, H. \& Müller, A., 1996. Hydrographie und Klima im Lister Tidebecken. In: SWAP - Sylter Wattenmeer Austauschprozesse - Projektsynthese. Boysen, Tönning, 32-45.

Bayerl, K., Austen, I., Köster, R., Pejrup, M. \& Witte, G., 1996. Dynamik der Sedimente im Lister Tidebecken. In: SWAP - Sylter Wattenmeer Austauschprozesse - Projektsynthese. Boysen, Tönning, 103-131.

Bodenbender, J. \& Papen, H., 1996. Bedeutung gasförmiger Komponenten an den Grenzflächen Sediment/Atmosphäre und Wasser/Atmosphäre. In: SWAP - Sylter Wattenmeer Austauschprozesse - Projektsynthese. Boysen, Tönning, 252-278.

Boudreau, B. P., 1987. A steady-state diagenetic model for dissolved carbonate species and $\mathrm{pH}$ in the porewaters of oxic and suboxic sediments. - Geochim. Cosmochim. Acta 51, 1985-1996.

Bower, C. E. \& Holm-Hansen, T., 1980. A salicylate-hypochlorite method for determining ammonia in seawater. - Can. J. Fish. aquat. Sci. 37, 794-798.

Cadée, G. C., 1976. Sediment reworking by Arenicola marina on tidal flats in the Dutch Wadden Sea. - Neth. J. Sea Res. 10, 440-460.

Cadée, G. C. \& Hegeman, J., 1977. Distribution of primary production of the benthic microflora and accumulation of organic matter on a tidal flat area, Balgzand, Dutch Wadden Sea. - Neth. J. Sea Res. 11, 24-41.

Camacho-Ibar, V.F. \& Alvarez-Borrego, S., 1988. Nutrient concentrations in pore waters of intertidal sediments in a coastal lagoon: Patchiness and temporal variations. - Sci. total. Environ. 75, 325-339.

Cammen, L. M., 1991. Annual bacterial production in relation to benthic microalgal production and sediment oxygen uptake in an intertidal sandflat and an intertidal mudflat. - Mar. Ecol. Prog. Ser. $71,13-25$.

Colijn, F. \& Buurt, G. van, 1975. Influence of light and temperature on the photosynthetic rate of marine benthic diatoms. - Mar. Biol. 31, 209-214.

Colijn, F. \& Jonge, V. N. de, 1984. Primary production of microphytobenthos in the Ems-Dollard estuary. - Mar. Ecol. Prog. Ser. 14, 185-196.

Connor, M. S., Teal, J. M. \& Valiela, I., 1982. The effect of feeding by mud snails, Ilyanassa obsoleta (Say), on the structure and metabolism of a laboratory benthic algal community. - J. exp. mar. Biol. Ecol. 65, 29-45.

Davis, M. W. \& Lee, H., 1983. Recolonization of sediment-associated microalgae and effects of estuarine infauna on microalgal production. - Mar. Ecol. Prog. Ser. 11, 227-232.

Davis, M. W. \& McIntire, C. D., 1983. Effects of physical gradients on the production dynamics of sediment-associated algae, - Mar. Ecol. Prog. Ser. 13, 103-114. 
Duyl, F. C. van \& Kop, A. J., 1990. Seasonal patterns of bacterial production and biomass in intertidal sediments of the western Wadden Sea. - Mar. Ecol. Prog. Ser. 59, 249-261.

Eppley, R. W., 1981. Relations between nutrient assimilation and growth in phytoplankton with a brief review of estimates of growth rate in the ocean. - Can. Bull. Fish. aquat. Sci. 210, 251-263.

Es, F. B. van, 1982. Community metabolism of intertidal flats in the Ems-Dollard estuary. - Mar. Biol. $66,95-108$.

Gardner, L. R., 1973. The effect of hydrologic factors on the pore water chemistry of intertidal marsh sediments. - Southeast. Geol. 15, 17-28.

Grant, J., 1986. Sensitivity of benthic community respiration and primary production to changes in temperature and light. - Mar. Biol. 90, 299-306.

Hall, P. O. J. \& Aller, R. C., 1992. Rapid, small-volume flow-injection analysis for $\mathrm{\Sigma CO}_{2}$ and $\mathrm{NH}_{4}{ }^{+}$in marine and freshwaters. - Limnol. Oceanogr. 37, 1113-1119.

Hall, S. J., Raffaelli, D. J., Basford, D. J. \& Robertson, M. R., 1990. The importance of flatfish predation and disturbance on marine benthos: an experiment with dab Limanda limanda (L.). - J. exp. mar. Biol. Ecol. 136, 65-76.

Hargrave, B. T., Prouse, N. J., Phillips, G. A. \& Neame, P. A., 1983. Primary production and respiration in pelagic and benthic communities at two intertidal sites in the upper Bay of Fundy. - Can. J. Fish. aquat. Sci. 40, 229-243.

Henriksen, K., Jensen, A. \& Rasmussen, M. B., 1984. Aspects of nitrogen and phosphorus mineralization and recycling in the northern part of the Danish Wadden Sea. - Publ. Ser. Neth. Inst. Sea Res. 10, 51-69.

Hickel, W., 1989. Inorganic micronutrients and the eutrophication in the Wadden Sea of Sylt (German Bight, North Sea). In: Proceedings of the 21st European Marine Biology Symposium. Ed. by R. Z. Klekowski, E. Styczyñska-Jurewicz and L. Falkowski. Polish Academy of Sciences, Wroclaw, 309-318.

Jensen, M. H., Lomstein, E. \& Sørensen, J., 1990. Benthic $\mathrm{NH}_{4}{ }^{+}$and $\mathrm{NO}_{3}{ }^{-}$flux following sedimentation of a spring phytoplankton bloom in Aarhus Bight, Denmark. - Mar. Ecol. Prog. Ser. 61. $87-96$.

Jensen, K. M., Jensen, M. H. \& Kristensen, E., 1996. Nitrification and denitrification in Wadden Sea sediments (Königshafen, Island of Sylt, Germany) as measured by nitrogen isotope pairing and isotope dilution. - Aquat. microb. Ecol. 11, 181-191.

Jong, D. J. de \& Jonge, V. N. de, 1995. Dynamics and distribution of microphytobenthic chlorophyll-a in the Western Scheldt estuary (SW Netherlands). - Hydrobiologia 311, 21-30.

Jonge, V. N. de, 1980. Fluctuations in the organic carbon to chlorophyll a ratios for estuarine benthic diatom populations. - Mar. Ecol. Prog. Ser. 2, 345-353.

Jonge, V. N. de \& Beusekom, J. E. E. van, 1995. Wind- and tide-induced resuspension of sediment and microphytobenthos from tidal flats in the Ems estuary. - Limnol. Oceanogr. 40, 766-778.

Jørgensen, B. B. \& Sørensen, J., 1985. Seasonal cycles of $\mathrm{O}_{2}, \mathrm{NO}_{3}{ }^{-}$and $\mathrm{SO}_{4}{ }^{2-}$ reduction in estuarine sediments: the significance of an $\mathrm{NO}_{3}{ }^{-}$reduction maximum in spring. - Mar. Ecol. Prog. Ser. 24, $65-74$.

Kristensen, E., 1993. Seasonal variations in benthic community metabolism and nitrogen dynamics in a shallow, organic-poor Danish lagoon. - Estuar. coast. Shelf Sci. 36, 565-586.

Kristensen, E. \& Hansen, K., 1995. Decay of plant detritus in organic-poor marine sediment: Production rates and stoichiometry of dissolved $\mathrm{C}$ and $\mathrm{N}$ compounds. $-\mathrm{J}$. mar. Res. 53, 675-702.

Kristensen, E., Devol, A. H., Ahmed, S. I. \& Saleem, M., 1992. Preliminary study of benthic metabolism and sulfate reduction in a mangrove swamp of the Indus Delta, Pakistan. - Mar. Ecol. Prog. Ser. 90, 287-297.

Kristensen, E., King, G. M., Holmer, M., Banta, G. T., Jensen, M. H., Hansen, K. \& Bussarawit, N., 1994. Sulfate reduction, acetate turnover and carbon metabolism in sediments of the Ao Nam Bor mangrove, Phuket, Thailand. - Mar. Ecol. Prog. Ser. 109, 245-255.

Moeslund, L., Thamdrup, B. \& Jørgensen, B. B., 1994. Sulfur and iron cycling in a coastal sediment: Radiotracer studies and seasonal dynamics. - Biogeochemistry 27, 129-152.

Nowicki, B. L. \& Nixon, S. W., 1985a. Benthic community metabolism in a coastal lagoon ecosystem. - Mar. Ecol. Prog. Ser. 22, 21-30.

Nowicki, B. L. \& Nixon, S. W., 1985b. Benthic nutrient remineralization in a coastal lagoon ecosystem. - Estuaries $8,182-190$. 
Parsons, T. R., Maita, Y. \& Lalli, C. M., 1984. A Manual of Chemical and Biological Methods for Seawater Analysis. Pergamon Press, Oxford, $173 \mathrm{pp}$.

Parsons, T. R., Stephens, K. \& Strickland, J. D. H., 1961. On the chemical composition of eleven species of marine phytoplankters. - J. Fish. Res. Bd Can. 18, 1001-1016.

Raffaelli, D. \& Milne, H., 1987. An experimental investigation of the effects of shorebird and flatfish predation on estuarine invertebrates. - Estuar. coast. Shelf Sci. 24, 1-13.

Rasmussen, M. B., Henriksen, K. \& Jensen, A., 1983. Possible causes of temporal fluctuations in primary production of the microphytobenthos in the Danish Wadden Sea. - Mar. Biol. 73, 109-114.

Reise, K., Herre, E. \& Sturm, M., 1994. Biomass and abundance of macrofauna in intertidal sediments of Königshafen in the northern Wadden Sea. - Helgoländer Meeresunters. 48, 201-215.

Rizzo, W. M., 1990. Nutrient exchanges between the water column and a subtidal benthic microalgal community. - Estuaries 13, 219-226.

Rysgaard, S., Risgaard-Petersen, N., Nielsen, L. P. \& Revsbech, N. P., 1993. Nitrification and denitrification in lake and estuarine sediments measured by the ${ }^{15} \mathrm{~N}$ dilution technique and isotope pairing. - Appl. environ. Microbiol. 59, 2093-2098.

Rysgaard, S., Christensen, P. B. \& Nielsen, L. P., 1995. Seasonal variation in nitrification and denitrification in estuarine sediment colonized by benthic microalgae and bioturbating infauna. - Mar. Ecol. Prog. Ser. 126, 111-121.

Sampou, P. \& Oviatt, C. A., 1991. Seasonal patterns of sedimentary carbon and anaerobic respiration along a simulated eutrophication gradient. - Mar. Ecol. Prog. Ser. 72, 271-282.

Solorzano, L., 1969. Determination of ammonia in natural waters by the phenolhypochlorite method. - Limnol. Oceanogr. 14, 799-801.

Sundbäck, K. \& Graneli, W., 1988. Influence of microphytobenthos on the nutrient flux between sediment and water: a laboratory study. - Mar. Ecol. Prog. Ser. 43, 63-69.

Sundbäck, K., Enoksson, V., Graneli, W. \& Pettersson, K., 1991. Influence of sublittoral microphytobenthos on the oxygen and nutrient flux between sediment and water: a laboratory continuousflow study. - Mar. Ecol. Prog. Ser. 74, 263-279.

Therkildsen, M. S. \& Lomstein, B. Aa., 1993. Seasonal variation in net benthic C-mineralization in a shallow estuary. - FEMS Microbiol. Ecol. 12, 131-142.

Thrush, S. F., Pridmore, R. D., Hewitt, J. E. \& Cummings, V. J., 1994. The importance of predators on a sandflat: interplay between seasonal changes in prey densities and predator effects. - Mar. Ecol. Prog. Ser. 107, 211-222. 